J. Lake Sci. (湖泊科学), 2018, 30(4): 1097-1108

DOI 10. 18307/2018. 0422

(c) 2018 by Journal of Lake Sciences

\title{
珠江干流梯级开发对鱼类的影响与减缓对策”
}

\author{
陈 锋, 雷 欢, 郑海涛, 王文君, 方艳红, 杨 钟, 黄道明 \\ (水利部中国科学院水工程生态研究所,水利部水工程生态效应与生态修复重点实验室,武汉 430079)
}

\begin{abstract}
摘 要: 2013 年 6-7 月对珠江龙滩库尾至长洲坝下江段干支流鱼类进行了调查,共采集到鱼类 6418 尾,隶属于 10 目 23 科 82 属 122 种. 分析了渔获物的种类组成与分布、生态类型、珍稀濒危特有鱼类采样情况、各江段群落相似度和鱼类多样 性等, 并与该区域鱼类历史记录进行了对比分析. 总体来看,珠江干流梯级开发后, 由于大坝阻隔、水文情势改变等,鱼类 资源发生了较大变化, 河海洄游性鱼类和河口鱼类受大坝阻隔影响分布范围变窄; 珍稀濒危特有鱼类由于生境破坏, 种 群规模变小,濒危程度加剧; 库中江段流水性鱼类种类数和资源量显著下降,静缓流鱼类成为优势种; 外来鱼类种类多、 分布广. 对导致珠江干流鱼类资源衰退的其他原因进行了分析, 主要包括过度捕捞、生境破坏、水污染和外来鱼类人侵等. 针对珠江干流梯级开发及鱼类资源现状, 提出了栖息地保护、河流连通性恢复、鱼类增殖放流站建设、生态调度、渔政管 理和生态补偿等措施建议.
\end{abstract}

关键词: 珠江;梯级开发;鱼类;影响;减缓对策

\section{Impacts of cascade reservoirs on fishes in the mainstream of Pearl River and mitigation measures}

CHEN Feng, LEI Huan, ZHENG Haitao, WANG Wenjun, FANG Yanhong, YANG Zhong \& HUANG Daoming

(Key Laboratory of Ecological Impacts of Hydraulic-Projects and Restoration of Aquatic Ecosystem of Ministry of Water Resources, Institute of Hydroecology, Ministry of Water Resources and Chinese Academy of Sciences, Wuhan 430079, P.R.China)

\begin{abstract}
The fish resources in the mainstream and its tributaries of the Pearl River from Longtan Dam to Changzhou Dam were investigated in June-July 2013. A total of 6418 fish specimens were collected, belonging to 10 orders, 23 families, 82 genera and 122 species. This study analysed the species composition and distribution, ecological types of fishes, sampling result of rare and endemic fish, the community similarity and diversity of fishes of each sample reach, and compared with the historical record. Overall, after cascade reservoirs in the Pearl River, massive changes in fish resources had taken place, such as river migratory fish and estuarine fish distribution range becoming narrow due to the dam barrier effect; rare and endemic fish being more endangered due to habitat loss; flow water fish species decreasing significantly in the reservoirs, while the static flow fish becoming the dominant species; and exotic fish species multiplying and distributing widely. Some other reasons for the decline of fish resources in the Pearl River mainstream were analysed, including overfishing, habitat destruction, water pollution, invasion of exotic fish and so on. In view of the Pearl River cascade reservoirs and the status of fishery resources, this study proposed mitigation measures such as habitat protection, restoration of river connectivity, fish breeding and releasing station construction, ecological scheduling, fishery management and ecological compensation.
\end{abstract}

Keywords: Pearl River; cascade reservoirs; fish; impact; mitigation measures

珠江由西江、北江、东江及珠江三角洲诸河组成. 西江、北江和东江汇人珠江三角洲后, 经八大口门注人 南海, 形成“三江汇流, 八口出海” 的水系结构. 其中, 西江发源于云南省曲靖市乌蒙山余脉的马雄山东麓, 自

* 国家自然科学基金项目 (51609159) 和国家重点基础研究发展计划 (2016YFA0601001) 联合资助. 2017-09-12 收 稿;2017-10-30 收修改稿. 陈锋(1981 ), 男, 博士, 副研究员; E-mail: chenfeng@ mail.ihe.ac.cn. 
西向东流经云南、贵州、广西和广东 4 省 (自治区), 至广东省佛山市三水区的思贤浫与北江汇合后流人珠江 三角洲河网区, 流域面积 35.31 万 $\mathrm{km}^{2}$, 占珠江流域总面积的 $77.8 \%$, 是珠江流域的主流. 西江干流全长 2075 $\mathrm{km}$,依次由南盘江、红水河、黔江、浔江及西江等江段组成.

珠江流域跨越云南、贵州、广西、广东、江西和湖南等省, 流域内地形复杂、地貌多样, 支流众多和水系复 杂. 珠江流域位于我国南部低纬度季风地区, 水热条件十分丰富 ${ }^{[1]}$. 正是由于其多样性的生境和丰富的水热 资源, 孕育了多样性的鱼类. 珠江流域共分布有淡水鱼类 472 种和亚种, 其中珠江水系特有鱼类 174 种 $^{[2]}$, 居我国各流域之首.

《红水河综合利用规划报告》(1981 年)在红水河干流规划了 10 座梯级, 从上游至下游依次为: 天生桥 一级、天生桥二级、平班、龙滩、岩滩、大化、百龙滩、乐滩、桥巩及大藤峡, 总装机容量为 $12000 \mathrm{MW}$, 年发电量 约 600 亿 $\mathrm{kW} \cdot \mathrm{h}^{[3]}$. 迄今为止, 除大藤峡梯级在建外, 其他梯级均已建成投产 (龙滩远期 $400 \mathrm{~m}$ 方案未实 施), 另外浔江上已建成长洲水利枢纽. 梯级开发导致河流阻隔和生境破碎化、径流分布时空格局的改变等, 严重影响鱼类生存, 导致鱼类分布格局和多样性的变化 ${ }^{[4]}$. 本研究重点针对珠江干流龙滩水电站至长洲水 电站干支流进行鱼类资源调查, 并与历史资料进行对比分析, 探讨梯级开发对珠江鱼类多样性及其资源的 影响,并提出针对性的减缓和保护措施, 以期为珠江流域鱼类保护提供参考.

\section{1 材料与方法}

\section{1 采样方法}

本研究调查时间为 2013 年 6-7 月, 调查范围为平班坝下至桂江河口 (约 $1000 \mathrm{~km}$ ) 的珠江干支流, 其中 干流 14 个调查江段, 支流 11 条(图 1). 图中编号 1 14 分别为干流采样江段: 龙滩库尾、龙滩库中、岩滩库 尾、岩滩库中、大化库尾、大化库中、百龙滩、乐滩库尾、乐滩库中、桥巩库中、大藤峡库尾江段、大藤峡库中江 段、长洲库尾和长洲库中,编号 $15 \sim 25$ 分别为支流采样江段: 北盘江、蒙江、曹渡河、布柳河、盘阳河、灵岐河、 了江、柳江、郁江、濛江和桂江.

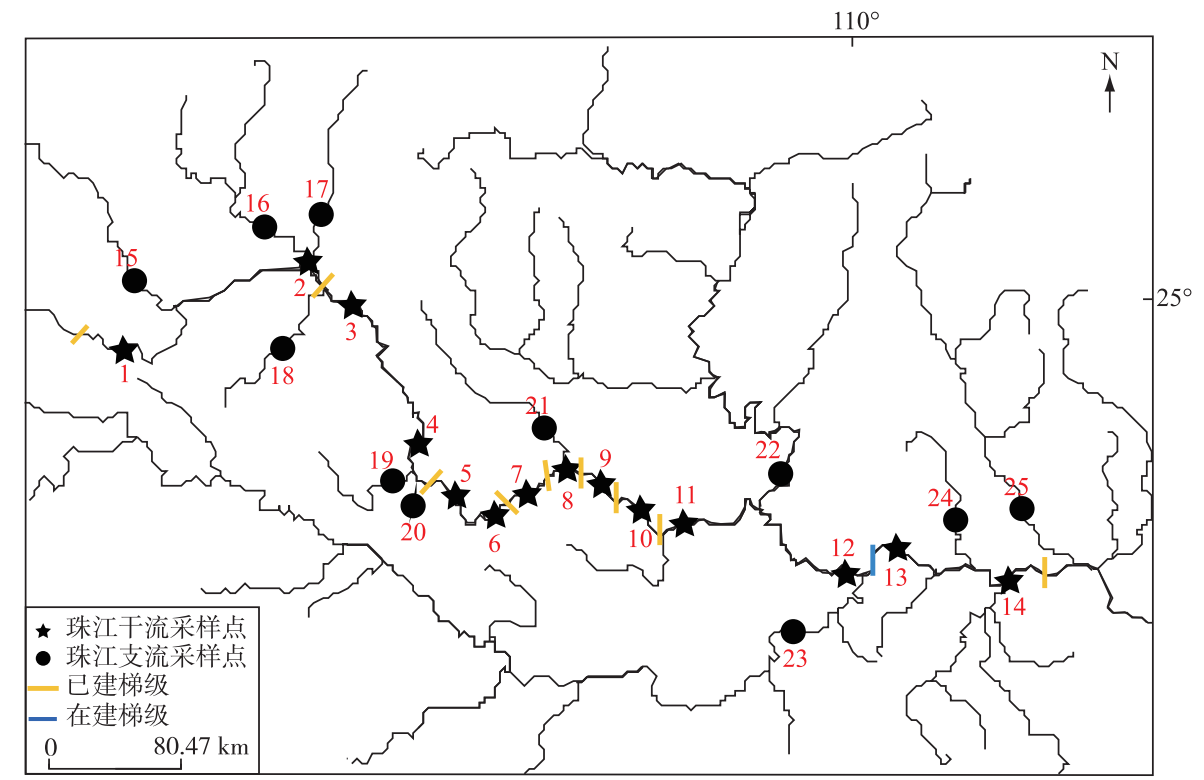

图 1 鱼类资源调查江段分布

Fig.1 Sampling sites distribution of fish resources investigation

干流从龙滩到长洲 8 个梯级 (含大藤峡), 除百龙滩 (库区较短, 仅 $27.6 \mathrm{~km}$, 且为径流式电站, 库区均为 流水状态) 和桥巩 (库尾流水江段较短, 库尾库中渔获物未分开统计) 外, 每个梯级均分库尾流水江段和库中 
静水江段开展调查; 大藤峡未建成, 规划坝址至上一级桥巩坝址江段长约 $190 \mathrm{~km}$, 江段较长, 仍根据规划成 库后的情况分为库尾江段和库中江段进行调查. 支流的调查范围主要是各支流最下游梯级至河口江段.

每个采样江段联系 1 3 位当地渔民, 要求他们在指定区域进行捕捞, 并收集每位渔民每天全部的渔获 物, 对不同渔民、不同网具和不同区域的渔获物分别进行统计,记录采集地点、网具和采样点生境状况等信 息. 每个采样点采用多种种类和规格网具, 如刺网和地笼等, 力争捕获到该江段从底层、中层到表层的不同 水层鱼类及不同规格鱼类. 每个江段采样时间为 $3 \sim 5 \mathrm{~d}$.

鱼类种类依据相关文献 ${ }^{[1,5-8]}$ 进行鉴定.

\section{2 鱼类生态类型划分}

鱼类的生态类型主要包括栖息类型、食性和繁殖习性,其中栖息类型的划分目前未见相关文献,且有些 鱼类对生境的适应性较强, 如鲫一般被认为是静水性鱼类, 但其在流水中亦能较好生存. 本研究根据珠江水 系鱼类特点、相关文献对各种类的描述及作者经验,将鱼类的栖息类型划分为底栖急流类群、缓流类群和静 水类群.

鱼类的食性主要参考文献 [9], 并将原文献中的碎屑食性也归为杂食性, 将草食性修订为植食性. 食性 划分为植食性、肉食性和杂食性.

鱼类的繁殖类型主要参考文献 [10], 为便于统计, 并将原文献中的泡沫巢浮性卵归为为浮性卵, 将缠丝 卵归为粘性卵. 繁殖类型划分为卵胎生、浮性卵、漂流性卵、粘沉性卵、粘性卵、蚌内产卵和筑巢产卵等 7 类.

具体划分标准如下:栖息类型: (1) 急流底栖类群,部分种类具特化的吸盘或类似吸盘的附着结构,适于 附着在急流河底物体上生活, 也有少数头部不具特化的吸附结构但习惯于生活于急流的种类; (2) 缓流类 群, 生活史的主要或全部阶段在江河流水环境中完成, 体长形, 略侧扁, 游泳能力强, 适应于中等流速的流水 生活; (3) 静水类群,一般喜生活于静水或微流水体中.

食性: (1) 植食性, 摄食植物性的食物, 即以高等水生维管束植物或低等藻类为食; (2) 肉食性, 以动物性 食物为主, 又可分为 3 个亚类型: 1 ) 凶猛肉食性, 通常以较大的活脊椎动物为食, 2 ) 温和肉食性, 主要以水中 的无脊椎动物为食, 3 ) 浮游动物食性, 以浮游甲壳类、桡足类、枝角类等为主食; ( 3 ) 杂食性, 对动植物性食物 都能取食的鱼类.

繁殖类型: (1) 卵胎生鱼类, 即卵在母体内发育成新的个体后才产出母体的生殖方式; (2) 产浮性卵鱼 类,包括卵黄带油滴和油球, 浮于水面发育的鱼类, 以及亲鱼吐气泡成漂浮巢, 卵浮于气泡下发育的鱼类; (3) 产漂流性卵鱼类, 在流水环境产卵,卵粒比重大于 1 , 静水中下沉, 凭流水漂流在水体中发育; (4) 产粘沉 性卵鱼类, 卵产于石质或泥沙质河床, 卵粒沉于石缝或粘附砂石上发育; (5) 产粘性卵鱼类, 产卵于水草而粘 附发育或缠丝挂在植物上发育; (6) 蛙内产卵鱼类, 产卵于蛙内发育; (7) 筑巢产卵鱼类, 亲鱼用鯺造成沙巢, 卵产巢内发育.

\section{3 数据处理}

1.3.1 多样性指数 对各江段鱼类多样性采用 Shannon-Wiener 指数 $\left(H^{\prime}\right) 、$ Pielou 指数 $\left(J^{\prime}\right) 、$ Margalef 物种丰富 度指数 $(D)$ 进行计算, 计算公式如下 ${ }^{[10-13]}$ :

$$
\begin{gathered}
H^{\prime}=-\sum\left(N_{i} / N\right) \ln \left(N_{i} / N\right) \\
J^{\prime}=H^{\prime} / \ln S \\
D=(S-1) / \ln N
\end{gathered}
$$

式中, $S$ 为种类数, $N_{i}$ 为种类 $i$ 的个体数, $N$ 为渔获物总个体数.

1.3.2 相对重要性指数 采用 Pinkas 相对重要性指数 (index of relative importance, IRI) 来研究鱼类群落优 势种 ${ }^{[14]}$ :

$$
I R I=\left(N_{i}+W_{i}\right) F
$$

式中, $N_{i}$ 为种类 $i$ 的个体数占总个体数的百分比, $W_{i}$ 为物种 $i$ 的重量百分比, $F$ 为某一种类出现次数占调查 总次数的百分比.

1.3.3 群落相似度 根据 Jaccard 相似性指数 $(q)$ 公式计算 ${ }^{[15]}$ :

$$
q=c /(a+b-c)
$$


式中, $c$ 为 2 个采样点共有的物种数, $a$ 和 $b$ 分别为 2 个采样点各自的物种数. 当 $q$ 在 $0 \sim 0.25$ 之间时为极不 相似; $0.25 \sim 0.50$ 之间为中等不相似; $0.50 \sim 0.75$ 之间为中等相似; $0.75 \sim 1.00$ 之间为极相似.

\section{2 结果}

\section{1 种类组成}

本次调查共采集渔获物 $439401.6 \mathrm{~g} 、 6418$ 尾, 隶属于 10 目 23 科 82 属 122 种 (附表). 其中鲱形目 2 科 2 属 2 种,占 $1.64 \%$; 鳂鳕目 1 科 1 属 2 种, 占 $1.64 \%$; 鲤形目 3 科 65 属 80 种, 占 $65.57 \%$; 鲇形目 6 科 9 属 17 种, 占 $13.93 \%$; 鲇形目 6 科 10 属 16 种,占 $13.11 \%$; 鲑形目、脂鲤目、鲟形目、合鳃鱼目和鲀形目均为 1 科 1 属 1 种,各占 $0.82 \%$.

鲤形目中按亚科一级统计, 以鲤科鲃亚科种类最多, 为 12 种, 鲌亚科和鮈亚科次之, 均为 11 种; 野鲮亚 科为 9 种; 沙鲀亚科、雅罗鱼亚科、鱊亚科、条鱾亚科和鲤亚科分别为 7 种、6种、5 种和 3 种; 花鲉亚科、(鱼 丹) 亚科、鲖亚科、平䰹䱊亚科和鲢亚科均为 2 种; 鲉鮀亚科和腹吸鱾亚科均为 1 种.

本次调查共发现外来鱼类 10 种, 分别为太湖新银鱼、短盖巨脂鲤、斑点叉尾鮰、食蚊鱼、鳛、革胡子鲇、 莫桑比克罗非鱼、尼罗罗非鱼、奥里亚罗非鱼和丁鱥,特别是尼罗罗非鱼在 25 个采样江段中的 20 个江段均 采集到, 且在总的渔获物中尾数百分比占 $7.25 \%$, 重量百分比占 $7.49 \%$, 在渔获物中的相对重要性指数为第 2 位(表 1).

\section{2 鱼类生态类型}

对采集到的 122 种鱼类的栖息类型、食性和繁殖习性等生态类型进行了划分. 按栖息类型划分, 急流底 栖类群鱼类 11 种, 占 $9.02 \%$; 缓流类群鱼类 75 种, 占 $61.48 \%$; 静水类群鱼类 36 种占 $29.51 \%$. 按食性划分, 植 食性鱼类 32 种, 占 $26.23 \%$; 肉食性鱼类 42 种, 占 $34.43 \%$; 杂食性鱼类 48 种, 占 $39.34 \%$. 按繁殖习性划分, 卵 胎生鱼类 1 种, 占 $0.82 \%$; 产浮性卵鱼类 8 种, 占 $6.56 \%$; 产漂流性卵鱼类 26 种, 占 $21.31 \%$; 产粘沉性卵鱼类 51 种, 占 $41.80 \%$; 产粘性卵鱼类 26 种, 占 $21.31 \%$; 蚌内产卵鱼类 5 种, 占 $4.10 \%$; 筑巢产卵鱼类 5 种, 占 $4.10 \%$. 另外日本鳗鳕、花鳗鲟和七丝鲚等 3 种为河海洄游性鱼类, 斑䰻、舌鰕虎鱼和斑东方鲀等 3 种为河口 鱼类 (表 2、附表).

\section{3 珍稀濒危特有鱼类采样情况}

本次调查仅在柳江发现 1 尾花鳗鲟,珠江流域分布的其他保护鱼类中华鲟、唐鱼和鲋均未发现; 在大藤 峡库中江段采集到稀有白甲鱼 1 尾; 在曹渡河采集到 18 尾暗色唇鲮; 在岩滩库中和乐滩库尾分别采集到 1 尾和 6 尾长慰鯔; 在郁江采集到 1 尾波纹鲭,其他列人红色名录的鱼类未采集到.

本次调查共采集到珠江水系特有鱼类 17 种, 分别为: 间鳃、花棘鳃、桂林䱊鮀、北江光唇鱼、多耙光唇鱼、 直口鲮、巴马拟缨鱼、卷口鱼、多线盘鮈、四须盘鮈、三角鲤、中华原吸鲉、伍氏华吸鱾、西江鲇、都安鲇、长臀 鮸和中间黄滪鱼. 采集到特有鱼类种类最多的是乐滩库尾、柳江和郁江 3 个江段 (支流), 均为 6 种; 其次为 大藤峡库中江段,采集到 5 种; 岩滩库尾采集到 4 种; 百龙滩、盘阳河和了江各采集到 3 种, 其他江段 (支流) 采集到的特有鱼类种类数较少. 大体来看, 采集到特有鱼类较多的江段多为流水生境或较大支流, 生境多样 性较高; 而库中江段采集到的特有鱼类较少,特别是龙滩库中、长洲库中等江段,未采集到特有鱼类. 在各江 段中出现频率最高的特有鱼类为四须盘鮈, 在 25 个采样江段的 11 个江段均采集到, 其次是卷口鱼、巴马拟 缨鱼和三角鲤,出现江段数依次为 $9 、 6$ 和 6 个,其他鱼类均只在 $1 \sim 3$ 个江段出现 (表 3 ).

\section{4 优势种组成}

表 1 列出了相对重要性指数前 40 位的鱼类,这 40 种鱼类占渔获物总尾数的 $87.13 \%$ 、总重量的 $91.72 \%$. 其中 IRI 值大于 500 的鱼类有 6 种, 依次为鲤、尼罗罗非鱼、斑鱯、子陵吻鰕虎鱼、卷口鱼和粲. IRI 值前 40 位 的种类中, 流水性鱼类 23 种, 占 $57.5 \%$; 珠江水系特有鱼类有卷口鱼、三角鲤、四须盘鮈和巴马拟缨鱼 4 种, 占 $10 \%$ (表 1$)$. 
表 1 渔获物中 IRI 值前 40 位的种类

Tab. 1 Fish species which the $I R I$ values in top 40 in the fish catches

\begin{tabular}{|c|c|c|c|c|c|c|c|c|}
\hline 编号 & 鱼名 & 尾数 & $\begin{array}{c}\text { 尾数 } \\
\text { 百分比 }\end{array}$ & 重量/g & $\begin{array}{c}\text { 重量 } \\
\text { 百分比 }\end{array}$ & 频度 & 频率 & $I R I$ 值 \\
\hline 1 & 鲤 & 158 & $2.46 \%$ & 53722.5 & $12.23 \%$ & 21 & $84.00 \%$ & 1233.80 \\
\hline 2 & 尼罗罗非鱼 & 465 & $7.25 \%$ & 32929.7 & $7.49 \%$ & 20 & $80.00 \%$ & 1179.16 \\
\hline 3 & 斑鱯 & 217 & $3.38 \%$ & 46676.4 & $10.62 \%$ & 20 & $80.00 \%$ & 1120.31 \\
\hline 4 & 子陵吻鰕虎鱼 & 803 & $12.51 \%$ & 1427.7 & $0.32 \%$ & 14 & $56.00 \%$ & 718.85 \\
\hline 5 & 卷口鱼 & 320 & $4.99 \%$ & 48649.5 & $11.07 \%$ & 9 & $36.00 \%$ & 578.08 \\
\hline 6 & 粲 & 380 & $5.92 \%$ & 7139.8 & $1.62 \%$ & 17 & $68.00 \%$ & 513.11 \\
\hline 7 & 赤眼鳟 & 210 & $3.27 \%$ & 27137.1 & $6.18 \%$ & 11 & $44.00 \%$ & 415.71 \\
\hline 8 & 大刺䲝 & 206 & $3.21 \%$ & 8262.0 & $1.88 \%$ & 19 & $76.00 \%$ & 386.84 \\
\hline 9 & 草鱼 & 66 & $1.03 \%$ & 28966.4 & $6.59 \%$ & 12 & $48.00 \%$ & 365.79 \\
\hline 10 & 瓦氏黄颡鱼 & 206 & $3.21 \%$ & 8269.1 & $1.88 \%$ & 16 & $64.00 \%$ & 325.86 \\
\hline 11 & 马口鱼 & 257 & $4.00 \%$ & 4304.0 & $0.98 \%$ & 15 & $60.00 \%$ & 299.03 \\
\hline 12 & 鲫 & 141 & $2.20 \%$ & 9928.9 & $2.26 \%$ & 16 & $64.00 \%$ & 285.22 \\
\hline 13 & 黄颡鱼 & 202 & $3.15 \%$ & 5791.4 & $1.32 \%$ & 14 & $56.00 \%$ & 250.06 \\
\hline 14 & 南方拟粲 & 139 & $2.17 \%$ & 5332.7 & $1.21 \%$ & 17 & $68.00 \%$ & 229.80 \\
\hline 15 & 三角鲤 & 73 & $1.14 \%$ & 22230.2 & $5.06 \%$ & 9 & $36.00 \%$ & 223.08 \\
\hline 16 & 广西副鱊 & 672 & $10.47 \%$ & 6580.9 & $1.50 \%$ & 4 & $16.00 \%$ & 191.49 \\
\hline 17 & 鯪 & 115 & $1.79 \%$ & 11823.0 & $2.69 \%$ & 8 & $32.00 \%$ & 143.44 \\
\hline 18 & 四须盘鮈 & 177 & $2.76 \%$ & 1859.1 & $0.42 \%$ & 11 & $44.00 \%$ & 139.96 \\
\hline 19 & 巴马拟缨鱼 & 215 & $3.35 \%$ & 3406.1 & $0.78 \%$ & 6 & $24.00 \%$ & 99.00 \\
\hline 20 & 鲢 & 12 & $0.19 \%$ & 14992.6 & $3.41 \%$ & 6 & $24.00 \%$ & 86.38 \\
\hline 21 & 翅嘴鲌 & 53 & $0.83 \%$ & 5743.9 & $1.31 \%$ & 7 & $28.00 \%$ & 59.72 \\
\hline 22 & 青鱼 & 16 & $0.25 \%$ & 9365.1 & $2.13 \%$ & 6 & $24.00 \%$ & 57.14 \\
\hline 23 & 海南鲌 & 37 & $0.58 \%$ & 3506.8 & $0.80 \%$ & 9 & $36.00 \%$ & 49.49 \\
\hline 24 & 纹唇鱼 & 102 & $1.59 \%$ & 2210.0 & $0.50 \%$ & 5 & $20.00 \%$ & 41.84 \\
\hline 25 & 南方白甲鱼 & 21 & $0.33 \%$ & 6699.5 & $1.52 \%$ & 5 & $20.00 \%$ & 37.04 \\
\hline 26 & 粗唇鮠 & 34 & $0.53 \%$ & 2636.8 & $0.60 \%$ & 8 & $32.00 \%$ & 36.16 \\
\hline 27 & 胡子鲇 & 17 & $0.26 \%$ & 2815.4 & $0.64 \%$ & 9 & $36.00 \%$ & 32.60 \\
\hline 28 & 鲇 & 17 & $0.26 \%$ & 2308.6 & $0.53 \%$ & 8 & $32.00 \%$ & 25.29 \\
\hline 29 & 大眼鳜 & 15 & $0.23 \%$ & 5413.3 & $1.23 \%$ & 4 & $16.00 \%$ & 23.45 \\
\hline 30 & 壮体沙鳅 & 57 & $0.89 \%$ & 340.0 & $0.08 \%$ & 6 & $24.00 \%$ & 23.17 \\
\hline 31 & 泥鳅 & 30 & $0.47 \%$ & 313.9 & $0.07 \%$ & 9 & $36.00 \%$ & 19.40 \\
\hline 32 & 䱻 & 10 & $0.16 \%$ & 2459.9 & $0.56 \%$ & 6 & $24.00 \%$ & 17.18 \\
\hline 33 & 东方墨头鱼 & 23 & $0.36 \%$ & 1081.4 & $0.25 \%$ & 7 & $28.00 \%$ & 16.93 \\
\hline 34 & 越南鲇 & 32 & $0.50 \%$ & 476.2 & $0.11 \%$ & 6 & $24.00 \%$ & 14.57 \\
\hline 35 & 银鮈 & 23 & $0.36 \%$ & 324.0 & $0.07 \%$ & 8 & $32.00 \%$ & 13.83 \\
\hline 36 & 倒刺鲃 & 9 & $0.14 \%$ & 3133.2 & $0.71 \%$ & 4 & $16.00 \%$ & 13.65 \\
\hline 37 & 大眼华鳊 & 27 & $0.42 \%$ & 946.2 & $0.22 \%$ & 5 & $20.00 \%$ & 12.72 \\
\hline 38 & 银鮰 & 14 & $0.22 \%$ & 1312.4 & $0.30 \%$ & 5 & $20.00 \%$ & 10.34 \\
\hline 39 & 光倒刺鲃 & 13 & $0.20 \%$ & 1892.2 & $0.43 \%$ & 4 & $16.00 \%$ & 10.13 \\
\hline 40 & 日本鳗鲡 & 8 & $0.12 \%$ & 605.9 & $0.14 \%$ & 5 & $20.00 \%$ & 5.25 \\
\hline
\end{tabular}


表 2 鱼类组成结构对比

Tab.2 Comparison of fish composition and structure

\begin{tabular}{|c|c|c|c|c|c|c|c|c|c|}
\hline & & \multicolumn{2}{|c|}{ 历史记录 [8] } & \multicolumn{2}{|c|}{2013 年采集 } & \multicolumn{2}{|c|}{ 数量对比 } & \multicolumn{2}{|c|}{ 百分比对比 } \\
\hline & & 数量 & 百分比 & 数量 & 百分比 & 变化 & 变幅 & 变化 & 变幅 \\
\hline \multirow[t]{3}{*}{ 属性 } & 国家级保护 & 3 & $1.86 \%$ & 1 & $0.82 \%$ & -2 & $-66.67 \%$ & $-1.04 \%$ & $-56.01 \%$ \\
\hline & 红色名录 & 17 & $10.56 \%$ & 5 & $4.10 \%$ & -12 & $-70.59 \%$ & $-6.46 \%$ & $-61.19 \%$ \\
\hline & 珠江水系特有 & 39 & $24.22 \%$ & 17 & $13.93 \%$ & -22 & $-56.41 \%$ & $-10.29 \%$ & $-42.48 \%$ \\
\hline \multirow[t]{5}{*}{ 生境类型 } & 洄游鱼类 & 7 & $4.35 \%$ & 3 & $2.46 \%$ & -4 & $-57.14 \%$ & $-1.89 \%$ & $-43.44 \%$ \\
\hline & 河口鱼类 & 5 & $3.11 \%$ & 3 & $2.46 \%$ & -2 & $-40.00 \%$ & $-0.65 \%$ & $-20.82 \%$ \\
\hline & 急流 & 22 & $13.66 \%$ & 11 & $9.02 \%$ & -11 & $-50.00 \%$ & $-4.65 \%$ & $-34.02 \%$ \\
\hline & 缓流 & 102 & $63.35 \%$ & 75 & $61.48 \%$ & -27 & $-26.47 \%$ & $-1.88 \%$ & $-2.97 \%$ \\
\hline & 静水 & 37 & $22.98 \%$ & 36 & $29.51 \%$ & -1 & $-2.70 \%$ & $6.53 \%$ & $28.40 \%$ \\
\hline \multirow[t]{3}{*}{ 食性 } & 植食性 & 48 & $29.81 \%$ & 32 & $26.23 \%$ & -16 & $-33.33 \%$ & $-3.58 \%$ & $-12.02 \%$ \\
\hline & 肉食性 & 58 & $36.02 \%$ & 42 & $34.43 \%$ & -16 & $-27.59 \%$ & $-1.60 \%$ & $-4.44 \%$ \\
\hline & 杂食性 & 55 & $34.16 \%$ & 48 & $39.34 \%$ & -7 & $-12.73 \%$ & $5.18 \%$ & $15.17 \%$ \\
\hline \multirow[t]{7}{*}{ 繁殖习性 } & 卵胎生 & 1 & $0.62 \%$ & 1 & $0.82 \%$ & 0 & 0 & $0.20 \%$ & $31.97 \%$ \\
\hline & 浮性卵 & 12 & $7.45 \%$ & 8 & $6.56 \%$ & -4 & $-33.33 \%$ & $-0.90 \%$ & $-12.02 \%$ \\
\hline & 漂流性卵 & 28 & $17.39 \%$ & 26 & $21.31 \%$ & -2 & $-7.14 \%$ & $3.92 \%$ & $22.54 \%$ \\
\hline & 粘沉性卵 & 83 & $51.55 \%$ & 51 & $41.80 \%$ & -32 & $-38.55 \%$ & $-9.75 \%$ & $-18.91 \%$ \\
\hline & 粘性卵 & 28 & $17.39 \%$ & 26 & $21.31 \%$ & -2 & $-7.14 \%$ & $3.92 \%$ & $22.54 \%$ \\
\hline & 蚌内产卵 & 4 & $2.48 \%$ & 5 & $4.10 \%$ & 1 & $25.00 \%$ & $1.61 \%$ & $64.96 \%$ \\
\hline & 筑巢产卵型 & 5 & $3.11 \%$ & 5 & $4.10 \%$ & 0 & 0 & $0.99 \%$ & $31.97 \%$ \\
\hline
\end{tabular}

\section{5 群落相似度}

对干流各江段渔获物的群落相似度进行计算, 结果见表 4. 总体上看, 除少数江段之间群落相似度为中 等相似外, 绝大部分江段之间的群落相似度均不高, 为极不相似或中等不相似. 其中大化库中与大化库尾、 大化库中与百龙滩、岩滩库尾与岩滩库中、岩滩库中与大化库尾、长洲库尾与长洲库中等相邻江段鱼类群落 相似度相对较高,而与龙滩库尾相似度最高的竟是与之相距最远的长洲库中江段.

\section{6 各江段鱼类生物多样性对比分析}

对各江段 Shannon-Wiener 指数、Pielou 指数和 Margalef 物种丰富度指数进行计算, 结果见表 5 , ShannonWiener 指数由高到低依次为: 柳江 $>$ 大藤峡库中江段 $>$ 郁江 $>$ 大藤峡库尾江段 $>$ 蒙江 $>$ 岩滩库中 $>$ 大化库尾 $>$ 长 洲库尾>布柳河 $>$ 桂江 $>$ 乐滩库尾>盘阳河 >灵岐河 $>$ J江 $>$ 北盘江 $>$ 长洲库中 $>$ 曹渡河 $>$ 大化库中 $>$ 百龙滩 $>$ 蒙 江 $>$ 乐滩库中 $>$ 桥巩库中 $>$ 龙滩库尾 $>$ 龙滩库中 $>$ 岩滩库尾; Pielou 均匀度指数由高到低依次为: 大化库尾 $>$ 大 藤峡库尾江段>乐滩库尾 $>$ 大藤峡库中江段 $>$ 郁江 $>$ 柳江 $>$ 濛江 $>$ 布柳河 $>$ 岩滩库中 $>$ 长洲库尾 $>$ 乐滩库中 $>$ 桥 巩库中 $>$ 桂江 $>$ 曹渡河 $>$ 灵岐河 $>$ 北盘江 $>$ ᄀ江 $>$ 盘阳河 $>$ 大化库中 $>$ 长洲库中 $>$ 蒙江 $>$ 百龙滩 $>$ 龙滩库尾 $>$ 龙滩 库中 $>$ 岩滩库尾; 种类丰富度指数由高到低依次为: 柳江 $>$ 郁江 $>$ 大藤峡库中江段 $>$ 大藤峡库尾江段 $>$ 桂江 $>$ 乐 滩库尾>长洲库中>岩滩库中>岩滩库尾 $>$ 盘阳河 $>$ 濛江 $>$ 万江 $>$ 百龙滩 $>$ 北盘江 $>$ 长洲库尾 $>$ 大化库尾 $>$ 布柳 河 $>$ 大化库中 $>$ 灵岐河 $>$ 蒙江 $>$ 曹渡河 $>$ 龙滩库中 $>$ 龙滩库尾>乐滩库中>桥巩库中.

将 25 个采集地依据其生境, 分为 3 组,其中 6 个库尾 (龙滩南盘江和北盘江、岩滩、大化、百龙滩、乐滩 和长洲)、大藤峡库中和大藤峡库尾列为第 1 组, 为流水环境; 10 条支流 (蒙江、漕渡河、布柳河、盘阳河、灵岐 河、习江、柳江、郁江、桂江和濛江) 列为第 2 组, 为支流流水环境; 6 个库中 (龙滩、岩滩、大化、桥巩、乐滩和长 洲) 列为第 3 组, 为静水环境. 对以上 3 组数据进行平均值比较, 发现在 Shannon-Wiener 指数、Pielon 均匀度 指数以及种类丰富度指数上, 均呈现出支流流水环境>库尾流水环境>库中静水环境. 对 3 组数据的 3 个指 数进行单因素方差分析, 结果表明: 只有支流流水环境组和静水环境组在 Shannon-Wiener 指数上呈显著差 异 $(\mathrm{Std}=0.27928, P=0.048)$. 


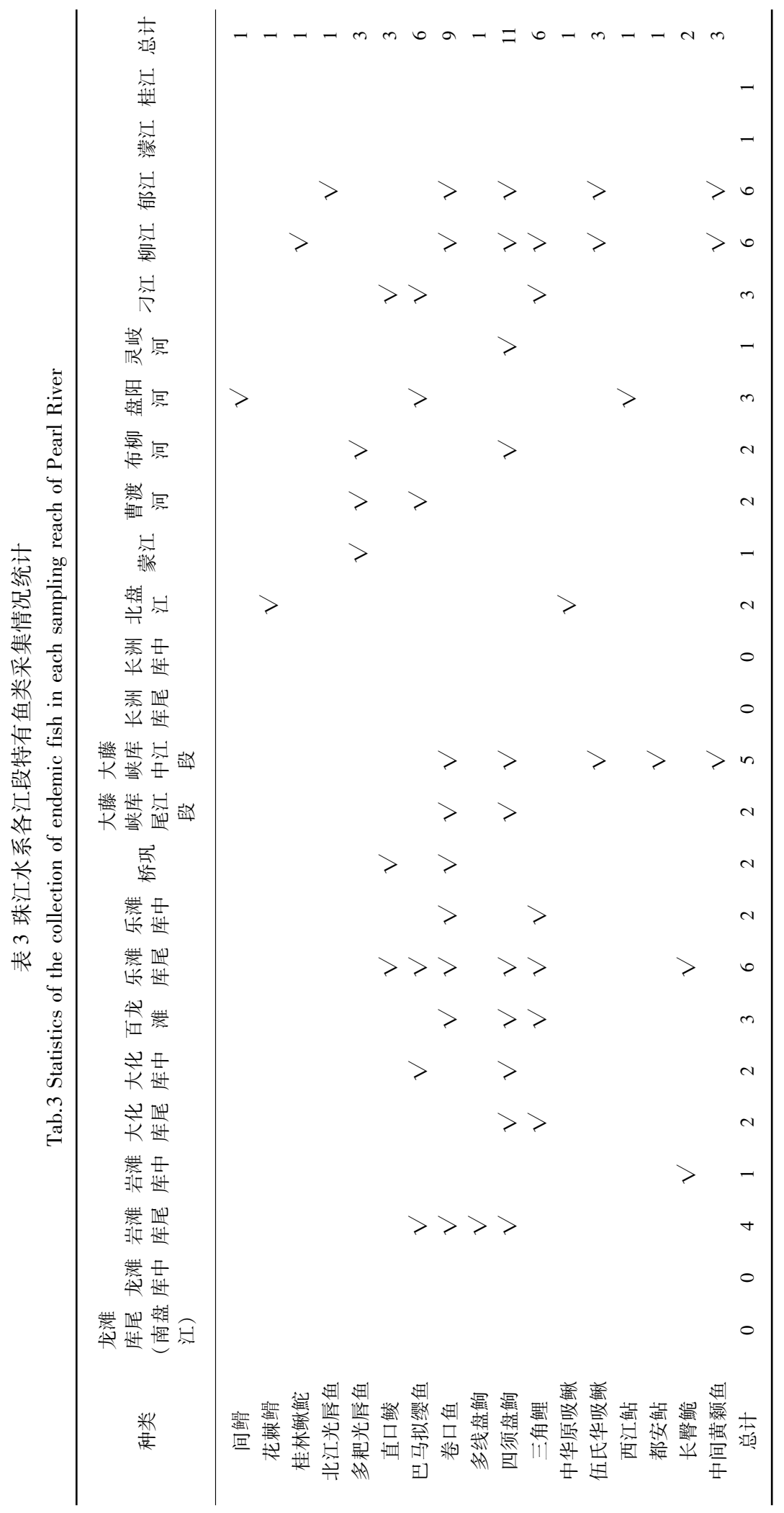


表 4 珠江干流不同江段鱼类群落相似度

Tab.4 Community similarity of each sampling reach in the mainstream of Pearl River

\begin{tabular}{|c|c|c|c|c|c|c|c|c|c|c|c|c|c|c|}
\hline 干流江段 & $\begin{array}{l}\text { 龙滩 } \\
\text { 库尾 }\end{array}$ & $\begin{array}{l}\text { 龙滩 } \\
\text { 库中 }\end{array}$ & $\begin{array}{l}\text { 岩滩 } \\
\text { 库尾 }\end{array}$ & $\begin{array}{l}\text { 岩滩 } \\
\text { 库中 }\end{array}$ & $\begin{array}{l}\text { 大化 } \\
\text { 库尾 }\end{array}$ & $\begin{array}{l}\text { 大化 } \\
\text { 库中 }\end{array}$ & $\begin{array}{c}\text { 百龙 } \\
\text { 滩 }\end{array}$ & $\begin{array}{l}\text { 乐滩 } \\
\text { 库尾 }\end{array}$ & $\begin{array}{l}\text { 乐滩 } \\
\text { 库中 }\end{array}$ & 桥巩 & $\begin{array}{c}\text { 大藤 } \\
\text { 峡 } \\
\text { 尾江段 }\end{array}$ & $\begin{array}{c}\text { 大藤 } \\
\text { 峡库 } \\
\text { 中江段 }\end{array}$ & $\begin{array}{l}\text { 长洲 } \\
\text { 库尾 }\end{array}$ & $\begin{array}{l}\text { 长洲 } \\
\text { 库中 }\end{array}$ \\
\hline 龙滩库尾 & & 0.30 & 0.21 & 0.31 & 0.29 & 0.18 & 0.27 & 0.26 & 0 & 0.14 & 0.16 & 0.18 & 0.27 & .36 \\
\hline 龙滩库中 & 0.30 & & 0.24 & 0.26 & 0.35 & 0.22 & 0.27 & 0.22 & 0.11 & 0.28 & 0.29 & 0.21 & 0.28 & 0.31 \\
\hline 岩滩库尾 & 0.21 & 0.24 & & 0.40 & 0.31 & 0.30 & 0.43 & 0.38 & 0.09 & 0.21 & 0.31 & 0.32 & 0.18 & 0.23 \\
\hline 岩滩库中 & 0.31 & 0.26 & 0.40 & & 0.39 & 0.32 & 0.35 & 0.31 & 0.12 & 0.25 & 0.16 & 0.17 & 0.18 & 0.28 \\
\hline 大化库尾 & 0.29 & 0.35 & 0.31 & 0.39 & & 0.58 & 0.54 & 0.33 & 0.25 & 0.32 & 0.21 & 0.21 & 0.19 & 0.26 \\
\hline 大化库中 & 0.18 & 0.22 & 0.30 & 0.32 & 0.58 & & 0.50 & 0.24 & 0.08 & 0.22 & 0.23 & 0.15 & 0.22 & 0.22 \\
\hline 百龙滩 & 0.27 & 0.27 & 0.43 & 0.35 & 0.54 & 0.50 & & 0.38 & 0.19 & 0.26 & 0.37 & 0.28 & 0.19 & 0.25 \\
\hline 乐滩库尾 & 0.26 & 0.22 & 0.38 & 0.31 & 0.33 & 0.24 & 0.38 & & 0.18 & 0.32 & 0.29 & 0.36 & 0.13 & 0.21 \\
\hline 乐滩库中 & 0.11 & 0.11 & 0.09 & 0.12 & 0.25 & 0.08 & 0.19 & 0.18 & & 0.24 & 0.15 & 0.14 & 0.08 & 0.10 \\
\hline 桥巩 & 0.14 & 0.28 & 0.21 & 0.25 & 0.32 & 0.22 & 0.26 & 0.32 & 0.24 & & 0.27 & 0.23 & 0.19 & 0.19 \\
\hline 大藤峡库尾江段 & 0.16 & 0.29 & 0.31 & 0.16 & 0.21 & 0.23 & 0.37 & 0.29 & 0.15 & 0.27 & & 0.36 & 0.24 & 0.20 \\
\hline 大藤峡库中江段 & 0.18 & 0.21 & 0.32 & 0.17 & 0.21 & 0.15 & 0.28 & 0.36 & 0.14 & 0.23 & 0.36 & & 0.18 & 0.26 \\
\hline 长洲库尾 & 0.27 & 0.28 & 0.18 & 0.18 & 0.19 & 0.22 & 0.19 & 0.13 & 0.08 & 0.19 & 0.24 & 0.18 & & 0.42 \\
\hline 长洲库中 & 0.36 & 0.31 & 0.23 & 0.28 & 0.26 & 0.22 & 0.25 & 0.21 & 0.10 & 0.19 & 0.20 & 0.26 & 0.42 & \\
\hline
\end{tabular}

表 5 珠江各江段鱼类生物多样性指数

Tab.5 Biodiversity indexes of fishes

in each sampling reach of Pearl River

\begin{tabular}{ccccc}
\hline 区域 & 江段 & $H^{\prime}$ & $J^{\prime}$ & $D$ \\
\hline 干流 & 龙滩库尾 & 1.30 & 0.47 & 2.39 \\
& 龙滩库中 & 1.26 & 0.47 & 2.44 \\
& 岩滩库尾 & 1.15 & 0.45 & 4.09 \\
& 岩滩库中 & 2.46 & 0.79 & 4.13 \\
& 大化库尾 & 2.37 & 0.90 & 3.30 \\
& 大化库中 & 2.00 & 0.67 & 3.05 \\
& 百龙滩 & 1.78 & 0.53 & 3.57 \\
& 乐滩库尾 & 2.28 & 0.86 & 4.22 \\
& 乐滩库中 & 1.51 & 0.77 & 1.91 \\
& 桥巩库中 & 1.37 & 0.73 & 1.38 \\
& 大藤峡库尾江段 & 2.83 & 0.89 & 5.03 \\
& 大藤峡库中江段 & 3.08 & 0.85 & 6.94 \\
& 长洲库尾 & 2.32 & 0.78 & 3.39 \\
长洲库中 & 2.11 & 0.65 & 4.18 \\
支流 & 北盘江 & 2.15 & 0.71 & 3.43 \\
& 蒙江 & 1.72 & 0.63 & 2.74 \\
& 曹渡河 & 2.03 & 0.72 & 2.51 \\
& 布柳河 & 2.30 & 0.81 & 3.20 \\
盘阳河 & 2.16 & 0.67 & 3.86 \\
灵岐河 & 2.16 & 0.71 & 2.98 \\
ᄀ江 & 2.16 & 0.68 & 3.64 \\
& 柳江 & 3.28 & 0.83 & 8.49 \\
& 郁江 & 3.07 & 0.84 & 7.14 \\
& 濛江 & 2.53 & 0.83 & 3.77 \\
& 桂江 & 2.30 & 0.72 & 4.33 \\
\hline & & & & \\
& & &
\end{tabular}

\section{3 讨论}

\section{1 鱼类种类组成比较}

通过本次调查, 总体来看, 珠江干流鱼类种类多 样性高,鱼类资源丰富, 但与历史资料对比,亦发生 了较大变化. 《广西淡水鱼类志 (第二版) $\rangle^{[8]}$ 记录的 红水河和浔江的鱼类共计 175 种, 这一区域基本上 与本研究区域重叠, 其中暗河鱼类有 14 种, 由于本 次调查未采集暗河鱼类, 因此在进行对比分析时将 这 14 种鱼类剔除, 因此本研究将除暗河鱼类外的 161 种鱼类作为本底, 研究鱼类资源的变化情况.

3.1 .1 鱼类种类数变化 对比本底的 161 种鱼类, 本 研究调查到的鱼类新增 38 种, 其中外来鱼类 10 种, 其他 28 种在珠江水系均有分布, 只是在该文献中没 有记录. 新增种类中有珠江水系特有鱼类 7 种, 无濒 危或易危种类; 从栖息类型来看, 有急流鱼类 1 种, 缓流鱼类 25 种, 静水鱼类 12 种.

但是在本底 161 种鱼类中,有 77 种本研究未采 集到, 其中有国家级保护动物中华鲟、鲋, 12 种濒危 或易危种类, 29 种珠江水系特有鱼类, 洄游性鱼类和 河口鱼类 7 种,急流或缓流鱼类 64 种.

3.1 .2 鱼类群落相似性 各江段渔获物群落相似度较 低(表 4), 在 25 个采样江段中, 出现频率超过 $50 \%$ 的 种类仅 4 种, 分别为鲤、尼罗罗非鱼、斑鱯和子陵吻 鰕虎鱼, 其他种类出现频率均较低 (表 4). 从这些数 据可以反映出, 梯级开发后, 鲤、子陵吻鰕虎鱼及外 
来鱼类罗非鱼等能够适应静缓流生境的种类分布最为广泛,而其他喜流水生境的土著鱼类, 呈现出点状不 连续分布, 导致其 $I R I$ 指数不高, 且各江段鱼类群落相似度不高, 从而也说明梯级开发对河流连通性的影响. 3.1.3 鱼类群落结构变化 对本底 161 种鱼类和本研究采集到的 122 种鱼类种类组成进行分析 (表 2), 结果 显示, 本研究采集到的 122 种鱼类中国家级保护鱼类、列入红色物种名录鱼类和珠江水系特有鱼类不管是 种类数还是在鱼类组成中所占比例均大幅减少; 从生境类型来看, 洄游鱼类、河口鱼类种类数和比例也大幅 下降, 适宜急流生境的鱼类比例下降显著, 而缓流鱼类比例下降不明显, 静水鱼类比例大幅增加; 从鱼类食 性来看, 植食性和肉食性鱼类的比例都有所下降, 而杂食性鱼类比例增加; 从鱼类繁殖习性来看, 原本占多 数的流水产粘沉性卵鱼类比例下降明显.

\section{2 梯级开发对鱼类的影响分析}

梯级电站的建设运行对鱼类资源的最显著的影响因素可能是阻隔作用和水文情势的改变,梯级开发将 原有的连续的河流生态系统切割成片段化的水库一河流生态系统, 库区及坝下水文情势发生巨大改变. 对洄 游性鱼类和河口鱼类等产生阻隔, 影响其完成生殖和索亚等生活史的必要过程, 同时也影响鱼类的分布及 种群间的交流. 在库区江段, 原河流型鱼类群落结构向湖泊水库型鱼类群落结构演替,一些原有的江河流水 性鱼类种类数量减少甚至消失, 而一些适应静水或缓流的鱼类及广适性鱼类逐步在群落中占据优势地位. 加之部分外来养殖鱼类的引人, 导致鱼类群落由高特异性、高多样性的原生型向普适性、低多样性的人工干 预型演替. 根据对不同江段鱼类多样性的统计分析, 在流水环境(支流、库尾) 中采集到的鱼类种类数和特有 鱼类种类数均明显高于库中静水生境, 相对于静水环境的库中, 流水环境的支流和库尾成为流水性鱼类残 存的栖息环境.

珍稀濒危特有鱼类往往是适应本流域某些特殊原生生境的种类, 水库形成后对其生境破坏大, 其种群 规模显著下降,濒危程度加剧. 珠江流域共分布有特有鱼类 174 种,特有比例高达 $36.9 \%$, 调查江段历史记录 珠江水系特有鱼类 46 种, 占 $28.6 \%$. 本次共调查到的特有鱼类仅 18 种, 占调查种数的 $14.8 \%$, 且出现频次和 数量均较少. 由此可见梯级开发对鱼类的影响,珍稀濒危特有鱼类首当其冲,梯级开发使珍稀濒危特有鱼类 濒危程度加剧.

本次调查还发现部分相似生活史类型鱼类在梯级开发胁迫及其他人类活动影响下, 其响应却截然不同. 以斑鱯和长臀鯔、卷口鱼和唇鲮这两组鱼类为例, 斑鱯为鲇形目魭科鱼类, 长慰鯔为鲇形目长臀鯔科鱼类, 分类地位相近、生态习性相似,均为流水性底栖鱼类, 主要以底栖无脊椎动物和小型鱼类为食; 卷口鱼和唇 鲮均为鲤形目鲤科野鲮亚科鱼类, 这两种鱼类分类地位更相近、生态习性相似, 也是流水性底栖鱼类, 杂食 性, 以硅藻和有机碎屑为主. 历史上, 这 4 种鱼类均是珠江流域广泛分布的重要的经济鱼类, 天然捕捞产量 较高, 1983 年调查斑鱯、长臀鯔、卷口鱼、唇鲮在东塔、三江口等江段的渔获物中尾数百分比分别为 $18.4 \%$ 、 $38.2 \% 、 7.6 \%$ 和 7.4\% ${ }^{[16]}$, 而 2013 年调查结果四种鱼类在渔获物中的 IRI 值分别为 $1120.31 、 1.86 、 578.08$ 和 $2.33^{[17]}$, 斑鱯和卷口鱼依然是红水河渔获物中的优势种, 而长臀鮠和唇鲮已成为偶见种, 且长臀鮸和唇鲮均 已被《中国物种红色名录》评定为“易危” ${ }^{[18]}$. 这两组鱼类, 斑鱯和长臀鮸、卷口鱼和唇鲮, 其个体大小相似, 分布区域也基本一致,因此其面临的捕捞强度等其他人类活动的干扰应该是相似的. 分类单元相近、生活史 特征相似的两种鱼类在梯级开发胁迫下其响应截然不同,其机理有待进一步研究.

不同开发方式对鱼类资源的影响程度也有所不同. 库区鱼类的演替与水库调节能力、水库调度运行方 式、库区水文情势等有关. 龙滩和岩滩两座大型水库,主库区鱼类以鳙、鲢、鲤、鲫、尼罗罗非鱼、鲮、太湖新银

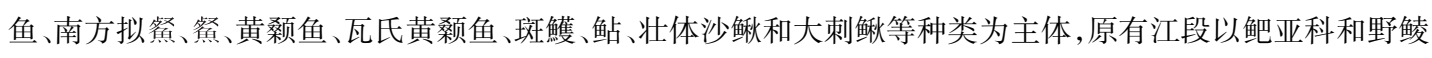
亚科为主的底栖流水性类群被压缩至库尾流水江段及部分支流的上游, 数量大为减少, 种类也向简单化发 展. 大化、百龙滩、乐滩及桥巩等日调节水库, 库容相对较小, 鳙、鲢等放养类群不及龙滩、岩滩水库, 原有的 流水性底鱼类也有一定数量分布, 但种类和数量有所减少. 总体来看径流式的电站相对于调节性能较强的 高坝大库对鱼类的种类组成与分布、珍稀濒危特有鱼类等的影响相对较小.

\section{3 影响鱼类的其他原因分析}

珠江干流鱼类资源的衰退是多因素的结果,除了梯级开发影响外,主要还有如下几方面原因.

(1) 酷鱼滥捕、过度捕捞是直接导致鱼类资源严重下降的主要原因之一, 本次调查并走访沿江群众, 普 
遍认同这一观点. 而且在当前鱼类资源已严重下降的情况下, 由于物以稀为贵, 野生鱼类的价格越来越高, 但正规渔具的渔获量越来越少,不少渔民被利益驱使渔具网目越来越小、捕捞方式越来越“先进”, 甚至采用 电鱼、毒鱼和炸鱼等非法方式,形成了恶性循环.

(2) 水污染和采砂等现象普遍. 本次调研发现珠江干流总体水质较好, 水体清澈,一般均能达到 III 类及 以上水质标准,但局部仍发现有点源污染,如盘阳河有洗矿水排人河中等污染现象, 对鱼类资源产生严重影 响. 另外, 局部江段捞石和采砂等活动频繁, 破坏河床底质, 影响鱼类繁殖、栖息和索㙁等, 甚至可能直接对 鱼类造成伤害.

(3) 外来鱼类对土著鱼类产生潜在危险. 本次调查共发现外来鱼类 10 种, 种类多、分布广, 特别是尼罗 罗非鱼在 25 个采样江段中的 20 个江段均采集到, 且在总的渔获物中尾数百分比占 $7.25 \%$, 重量百分比占 $7.49 \%$, 在渔获物中的相对重要性指数为第二位 (表 1). 人侵成功的外来鱼类一般都具有较强的耐受力和生 命力, 且繁殖能力强 (如罗非鱼、食蚊鱼等), 能迅速扩张种群并占领生态位, 直接挤占生存空间、食物竞争和 捕食土著鱼类的幼鱼和鱼卵、携带病菌和基因渗透等, 对土著鱼类产生巨大威胁, 甚至造成土著鱼类的濒危 和灭绝 ${ }^{[19]}$.

\section{4 减缓对策建议}

由于珠江干流大部分电站开发较早, 生态环境保护认识不强, 早期建设的梯级水电站并未提出有效的 保护措施, 近期建设的电站除长洲枢纽建设了鱼道, 桥巩电站和乐滩电站建设了鱼类增殖放流站外, 其他均 未采取具体的鱼类保护措施, 而且乐滩的增殖站只运行了 5 年便停止. 各个水库库区虽然也有增殖放流活 动, 但此类活动没有连续性, 且放养的品种单一, 多为草鱼、鲢、䲈、鲤等养殖鱼类, 仅能起到渔业增殖的作用. 而以喜流水生境为主的珍稀濒危特有鱼类基本没有开展增殖放流,难以满足流域鱼类资源保护要求.

根据“生态优先、统筹考虑、适度开发、确保底线” 的原则, 在系统研究梯级开发影响的基础上, 从河流生 态环境整体考虑, 形成上下游、干支流统筹保护的格局, 本研究建议以栖息地保护为主, 过鱼设施、增殖放 流、生态调度、渔政管理等多种保护措施为辅的综合保护体系, 同时开展长期的水生生态系统监测, 适时开 展保护效果评价,不断完善保护措施体系.

根据鱼类资源调查及生境现状, 建议栖息地保护以三大区域为主, 分别是乐滩库尾与ᄀ江、大藤峡库尾 与柳江、大藤峡坝下至磨刀门与郁江, 这三块区域分别位于上、中、下游, 且均是支流加干流的形式, 为鱼类 提供多样性的生境, 以承载多样性的鱼类. 同时通过修建过鱼设施, 使三大区域形成一个有机的整体. 另外 再加上局部生境的保护, 如各梯级库尾回水变动江段、支流汇口及下游流水江段等, 形成一个综合考虑了流 域不同区段的、复合型的栖息地保护体系.

过鱼设施方面, 龙滩、岩滩三个梯级由于离河口较远, 基本上没有洄游性鱼类分布, 且这个两个梯级均 为高坝大库, 并处于山区峡谷地带, 补建鱼道难度较大, 可补建集运鱼系统促进坝上坝下鱼类的基因交流; 岩滩以下各梯级坝高均不高, 河谷较宽阔, 且分布有洄游性鱼类日本鳗鳕、花鳗鲡等及产漂流性卵鱼类如四 大家鱼等, 补建过鱼设施十分必要; 大藤峡梯级在建, 且设计建设鱼道和仿自然通道两种过鱼设施, 长洲枢 纽已建鱼道. 因此若岩滩以下各梯级补建过鱼设施, 岩滩坝址以下至河口的珠江干流连通性能够得到较大 程度恢复.

增殖放流方面, 综合各梯级地理位置及现有增殖建设及规划情况, 龙滩梯级由于库区回水较长, 建议在 平班建设增殖放流站, 兼顾平班和龙滩的增殖放流任务, 可将放流鱼种投放在龙滩库尾和平班库尾或库中 江段, 减少长途运输对鱼苗的影响; 根据广西桂冠电力股份有限公司《红水河中游水电梯级 (岩滩、大化、百 龙滩和乐滩) 鱼类增殖放流设施建设总体规划》, 将岩滩、大化、百龙滩、乐滩四个梯级的增殖放流任务统筹 到大化增殖站, 该规划已获批即将实施; 在在建的大藤峡梯级附近桂平建设大藤峡增殖站, 负责大藤峡的增 殖放流任务; 在来宾建设特有鱼类增殖站, 重点针对来宾鱼类保护区开展特有鱼类的增殖放流, 同时在来宾 鱼类增殖站设立红水河珍稀鱼类保育中心, 重点开展全流域珍稀特有鱼类监测、科研、救护和繁育等工作. 增殖放流种类的确定, 需要坚持统筹兼顾、突出重点的原则, 根据珍稀濒危特有鱼类和重要经济鱼类分布情 况及受影响情况, 初步拟定各增殖放流站的放流对象如下: 平班增殖站: 倒刺鲃、光倒刺鲃、唇鲮和暗色唇 鲮, 大化增殖站: 长慰鯔、光倒刺鲃、倒刺鲃、三角鲤、乌原鲤和唇鯪, 桥巩增殖站: 南方白甲鱼、单纹似鳡、卷 
口鱼、乌原鲤和长慰鮠, 大藤峡增殖站: 唇鲮、暗色唇鲮、长慰鮸、斑鱯、光倒刺鲃、三角鲂、南方白甲鱼、赤眼 鳟、银鲖和黄尾鲖, 来宾珍稀鱼类保护增殖站: 乌原鲤、长慰鯔、单纹似䱛、长鯺光唇鱼、稀有白甲鱼、暗色唇 鲮、唇鲮、多线盘鮈和伍氏盘口鯪. 同时加强对增殖放流效果评估,适时调整放流规划.

借鉴长江三峡针对四大家鱼等繁殖需求开展生态调度的经验 ${ }^{[20]}$, 开展流域生态调度研究与试验. 考虑 龙滩为流域龙头水库, 调节库容大, 具备人造洪峰的调节能力; 桥巩水电站及大藤峡水电站下游分别为红水 河珍稀鱼类保护区及东塔产卵场, 有重要的鱼类产卵生境; 因此人造洪峰调度以龙滩水电站、桥巩水电站及 大藤峡水利枢纽为主, 龙滩下游其余梯级电站按来水下泄, 且在人造洪峰调度期间各电站发电调度不参与 调峰调频, 减小日内下泄流量的差异.

过渡捕捞和酷渔滥捕是威胁鱼类资源的直接因素, 因此要进一步加强流域渔政管理, 开展对沿江群众 生态环境保护的宣传和教育, 严格执行禁渔期制度, 坚决打击电鱼等非法捕捞行为. 严格采砂管理, 制定采 砂规划, 禁止在鱼类繁殖期及鱼类重要生境江段采砂. 探索生态补偿机制, 推进渔民转产转业, 逐步压减捕 捞强度,让鱼类休养生息.

致谢: 珠江水资源保护科学研究所谭细畅, 湖南农业大学江辉、吴含含、陈开健和刘巧林, 水利部中国科学院 水工程生态研究所赵娜、廖小林、阙延福和杨启红等参加了野外调查工作,在此一并致谢!

\section{4 附录}

附表见电子版(DOI: 10.18307/2018.0422).

\section{5 参考文献}

[ 1 ] Zheng CY. Fishes of Pearl River. Beijing: Science Press, 1989. [郑慈英. 珠江鱼类志. 北京:科学出版社, 1989.]

[ 2 ] Sui XY. Study on the distribution pattern of Chinese freshwater fishe[Dissertation] Wuhan: Institute of Hydrobiology, Chinese Academy of Sciences, 2010. [ 隋晓云. 中国淡水鱼类分布格局的研究 [学位论文]. 武汉: 中国科学院水生生物 研究所, 2010.]

[ 3 ] Pearl River Water Resources Commission of Ministry of Water Resources. Comprehensive utilization planning of Red River. 1981. [水利部珠江水利委员会. 红水河流域综合规划. 1981.]

[ 4 ] Chang JB, Chen YB, Gao Y et al. Effects of water conservancy and hydropower project on fish and countermeasures. Proceedings of the 2008 Conference of Chinese Institute of water conservancy (1). Beijing: Chinese Environmental Science Press, 2006: 239-253. [ 常剑波, 陈永柏, 高勇等. 水利水电工程对鱼类的影响及减缓对策. 中国水利学会 2008 学 术年会论文集 (上册). 北京: 中国环境科学出版社, 2006: 239-253.]

[ 5 ] Chen YY et al eds. Fauna Sinica, Osteichthyes, Cypriniformes II. Beijing: Science Press, 1998. [ 陈宜瑜等. 中国动物 志硬骨鱼纲鲤形目 (中卷). 北京: 科学出版社, 1998.]

[6] Yue PQ et al eds. Fauna Sinica, Osteichthyes, Cypriniformes III. Beijing: Science Press, 2000. [ 乐佩琦等. 中国动物志 硬骨鱼纲鲤形目 (下卷). 北京: 科学出版社, 2000.]

[ 7 ] Zhu SQ ed. Synopsis of freshwater fishes of China. Nanjing: Jiangsu Science and Technology Publishing House, 1995. [朱 松泉. 中国淡水鱼类检索. 南京: 江苏科学技术出版社, 1995.]

[ 8 ] Guangxi Zhuang Autonomous Region Fisheries Research Institute, Institute of Zoology, Chinese Academy of Sciences eds. Freshwater fishes of Guangxi, China (Second Edition). Nanning: Guangxi People's Publishing House, 2005. [广西壮族 自治区水产研究所, 中国科学院动物研究所. 广西淡水鱼类志(第二版). 南宁: 广西人民出版社, 2005.]

[ 9 ] Yi BL ed. Fish ecology. Wuhan: Huazhong Agricultural College, 1982: 2-3. [易伯鲁. 鱼类生态学. 武汉: 华中农学院, 1982: 2-3.]

[10] Liang ZS, Yi BL, Yu ZT eds. The early development of river fish (unpublished). 16-17. [梁秩㻏, 易伯鲁, 余志堂. 江 河鱼类的早期发育 (未出版). 16-17.]

[11] Shannon CE, Wiener WJ ed. The mathematical theory of communication. Urbana: University of Illinois Press, 1949 : 117.

[12] Pielou EC. Ecological diversity. New York: John Wiley and Sons, 1975.

[13] Margalef DR. Information theory in ecology. International Journal of General Systems, 1958, 3(1) : 36-71.

[14] Pinkas L, Oliphant MS, Iverson K. Food habits of albacore, bluefin tuna, and bonito in California waters. Fish Bulletin, 
1971, 152: 1-10.

[15] Xiang P, Liu LG, Wang D et al. Status and historical changes of fish resources of Wuqiangxi Reservoir on Yuanshui River in Hunan Province. J Lake Sci, 2016, 28(2) : 379-386. DOI:10.18307/2016.0218. [向鹏, 刘良国, 王冬. 湖南沅水 五强溪水库鱼类资源现状及其历史变化. 湖泊科学, 2016, 28(2) : 379-386. ]

[16] The Guangxi Zhuang Autonomous Region Fisheries Research Institute. Survey of natural resources of fisheries in inland waters of the Guangxi Zhuang Autonomous Region. 1984. [广西壮族自治区水产研究所. 广西壮族自治区内陆水域渔业 自然资源调查研究报告. 1984.]

[17] Institute of Hydroecology, Ministry of Water Resources and Chinese Academy of Sciences. Special report on aquatic ecology of retrospective study on environmental impact assessment of Hongshui River comprehensive utilization planning. 2014. [水 利部中国科学院水工程生态研究所. 红水河综合利用规划环境影响回顾性评价研究水生生态专题报告. 2014.]

[18] Wang S, Xie Y eds. Chinese species red list ( Vol 1 the red list). Beijing: Higher Education Press, 2004. [汪松, 解炎. 中国物种红色名录(第一卷红色名录). 北京: 高等教育出版社, 2004.]

[19] Li S, Chen JK, Wang XM. Global distribution, entry routes, mechanisms and consequences of invasive freshwater fish. Biodiversity Science, 2016, 24(6) : 672-685. [ 郥珊, 陈家宽, 王小明. 淡水鱼类人侵种的分布、人侵途径、机制与后 果. 生物多样性, 2016, 24(6): 672-685.]

[20] Xu W, Liu HG, Tang HY et al. Effects of ecological operation of Three Gorges Reservoir on fish eggs and larvae in Shashi section of the Yangtze River. Journal of Hydroecology, 2014, 35(2): 1-8. [徐薇, 刘宏高, 唐会元等. 三峡水库生态调 度对沙市江段鱼卵和仔鱼的影响. 水生态学杂志, 2014, 35(2) : 1-8.] 
附表 鱼类名录及生态类型

Appendix Tab List of fishes and their ecological types

\begin{tabular}{|c|c|c|c|c|c|c|c|c|c|c|}
\hline $\begin{array}{l}\text { 序 } \\
\text { 号 }\end{array}$ & 种类 & 目 & 科 & 亚科 & 属 & $\begin{array}{c}2013 \\
\text { 年 }\end{array}$ & $\begin{array}{l}\text { 文献 } \\
\text { 记录 }\end{array}$ & $\begin{array}{l}\text { 栖息 } \\
\text { 生境 }\end{array}$ & 食性 & $\begin{array}{l}\text { 繁殖 } \\
\text { 习性 }\end{array}$ \\
\hline 1 & 赤魟 Dasyatis akajei (EN) & 鲼形目 & 鯐科 & & 鯐属 & & + & MIG 、SLO & CAM & OVO \\
\hline 2 & * 中华鲟 Acipenser sinensis (EN) & 鲟形目 & 鲟科 & & 鲟属 & & + & MIG 、SLO & CAM & STD \\
\hline 3 & *鲋 Hilsa reevsii (EN) & 鲱形目 & 鲱科 & & 鲋属 & & + & MIG 、SLO & OMN & PEL \\
\hline 4 & 斑鰶 Konosirus punctatus & 鲱形目 & 鲱科 & & 斑䱕属 & V & & EST、SLO & HER & PEL \\
\hline 5 & 七丝鲚 Coilia grayii & 鲱形目 & 鯷科 & & 鲚属 & V & + & MIG 、SLO & CAM & PEL \\
\hline 6 & 日本鳗鲟 Anguilla japonica & 鳗鲡目 & 鳗鲡科 & & 鳗鲡属 & V & + & MIG、SLO & CAM & PEL \\
\hline 7 & * 花鳗鲖 A. marmorata (EN) & 鳗鲡目 & 鳗鲾科 & & 鳗鲡属 & V & + & MIG、SLO & CAM & PEL \\
\hline 8 & $\triangle$ 太湖新银鱼 Neosalanx taihuensis & 鮏形目 & 银鱼科 & & 新银鱼属 & V & & STI & CAM & STI \\
\hline 9 & 白肌银鱼 Leucosoma chinensis & 鲑形目 & 银鱼科 & & 白肌银鱼属 & & + & MIG 、SLO & CAM & PEL \\
\hline 10 & $\triangle$ 短盖巨脂鲤 Colossoma brachypomun & 脂鲤目 & 脂鲤科 & & 巨脂鲤属 & V & & STI & OMN & STI \\
\hline 11 & 美丽小条鱾 Micronemacheilus pulcher & 鲤形目 & 鱾科 & 条鱾亚科 & 小条鲉属 & V & + & SLO & OMN & PEL \\
\hline 12 & $\boldsymbol{\Delta}$ 丽纹云南鳅 $Y$. zebrinus & 鲤形目 & 鱾科 & 条鳅亚科 & 云南鱾属 & & + & SLO & OMN & STI \\
\hline 13 & $\boldsymbol{\Delta}$ 后鯺平鳅 0. retrodorsalis (VU) & 鲤形目 & 鱾科 & 条鳅亚科 & 平鳅属 & & + & SLO & OMN & STD \\
\hline 14 & $\mathbf{\Delta}$ 平头平鳅 O. platycephalus & 鲤形目 & 鱾科 & 条鳅亚科 & 平鿕属 & & + & SLO & OMN & STD \\
\hline 15 & 无斑南鲉 Schistura incerta & 鲤形目 & 鱾科 & 条鳅亚科 & 南䲝属 & V & + & SLO & OMN & STD \\
\hline 16 & 横纹南鱾 S. fasciolata & 鲤形目 & 鱾科 & 条鳅亚科 & 南鯻属 & V & + & SLO & OMN & STD \\
\hline 17 & 南方南鲉 S. meridionalis & 鲤形目 & 鳅科 & 条鳅亚科 & 南䲝属 & V & & SLO & OMN & STD \\
\hline 18 & 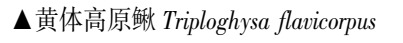 & 鲤形目 & 鳅科 & 条鳅亚科 & 高原鲀属 & & + & SLO & OMN & STD \\
\hline 19 & $\boldsymbol{\Delta}$ 南丹高原鳅 T. nandanensis & 鲤形目 & 鱾科 & 条鳅亚科 & 高原鲀属 & & + & SLO & OMN & STD \\
\hline 20 & 壮体沙鲉 Botia robusta & 鲤形目 & 鲉科 & 沙鳅亚科 & 沙鳅属 & V & + & SLO & OMN & PEL \\
\hline 21 & 美丽沙鲉 B. pulchra & 鲤形目 & 鲉科 & 沙鱾亚科 & 沙鿕属 & V & + & SLO & OMN & PEL \\
\hline 22 & 花斑副沙鱾 P. fasciata & 鲤形目 & 鳅科 & 沙鳅亚科 & 副沙鲉属 & V & + & SLO & OMN & PEL \\
\hline 23 & 点面副沙鳅 P. maculosa & 鲤形目 & 鱾科 & 沙鳅亚科 & 副沙鲉属 & & + & SLO & OMN & PEL \\
\hline 24 & 小副沙䲝 P. parva & 鲤形目 & 鱾科 & 沙鳅亚科 & 副沙鱾属 & V & & SLO & OMN & PEL \\
\hline 25 & 大斑薄鲉 Leptobotia pellegrini & 鲤形目 & 鱾科 & 沙鳅亚科 & 薄䲝属 & V & + & SLO & OMN & PEL \\
\hline 26 & $\Delta$ 斑纹薄鱾 L. zebra & 鲤形目 & 鲉科 & 沙鱾亚科 & 薄鲉属 & V & & SLO & OMN & PEL \\
\hline 27 & 薄鳅 L. pellegrini & 鲤形目 & 鱾科 & 沙鳅亚科 & 薄鳅属 & V & & SLO & OMN & PEL \\
\hline 28 & 中华花鳅 Cobitis sinensis & 鲤形目 & 鱾科 & 花鳅亚科 & 花䱊属 & V & + & SLO & OMN & PEL \\
\hline 29 & $\boldsymbol{\Delta}$ 沙花鳅 C. arenae & 鲤形目 & 鳅科 & 花鳅亚科 & 花鱾属 & & + & SLO & OMN & PEL \\
\hline 30 & 泥鳅 Misgurnus anguillicaudatus & 鲤形目 & 鱾科 & 花鳅亚科 & 泥鲉属 & V & + & STI & OMN & STI \\
\hline 31 & 南方波鱼 Rasbora steineri & 鲤形目 & 鲤科 & (鱼丹)亚科 & 波鱼属 & & + & SLO & OMN & STI \\
\hline 32 & 宽鳍鱲 Zacco platypus & 鲤形目 & 鲤科 & (鱼丹)亚科 & 鱲属 & V & + & SLO & OMN & STD \\
\hline 33 & 马口鱼 Opsarïchthys bidens & 鲤形目 & 鲤科 & (鱼丹)亚科 & 马口鱼属 & V & + & SLO & OMN & STD \\
\hline 34 & $\boldsymbol{\Delta}$ 瑶山鲤 Yaoshanicus arcus & 鲤形目 & 鲤科 & (鱼丹)亚科 & 瑶山鲤属 & & + & SLO & OMN & STI \\
\hline 35 & 青鱼 Mylopharyngodon piceus & 鲤形目 & 鲤科 & 雅罗鱼亚科 & 青鱼属 & V & + & SLO & CAM & PEL \\
\hline 36 & 鯮 Luciobrama macrocephalus (VU) & 鲤形目 & 鲤科 & 雅罗鱼亚科 & 鯮属 & & + & SLO & CAM & PEL \\
\hline 37 & 草鱼 Ctenopharyngodon idellus & 鲤形目 & 鲤科 & 雅罗鱼亚科 & 草鱼属 & V & + & SLO & HER & PEL \\
\hline 38 & 鲩 Ochetobius elongates & 鲤形目 & 鲤科 & 雅罗鱼亚科 & 鳤属 & V & + & SLO & CAM & PEL \\
\hline 39 & 鳡 Elopichthys bambusa & 鲤形目 & 鲤科 & 雅罗鱼亚科 & 鳡属 & V & + & SLO & CAM & PEL \\
\hline 40 & 赤眼鯂 Squaliobarbus curriculus & 鲤形目 & 鲤科 & 雅罗鱼亚科 & 赤眼鳟属 & V & + & SLO & HER & PEL \\
\hline 41 & $\triangle$ 丁鱥 Tinca tinca & 鲤形目 & 鲤科 & 雅罗鱼亚科 & 丁鱥属 & V & & SLO & OMN & STD \\
\hline 42 & 飘鱼 Pseudolaubuca sinensis & 鲤形目 & 鲤科 & 鲌亚科 & 飘鱼属 & V & + & SLO & OMN & STD \\
\hline 43 & 寡鳞飘鱼 P. engraulis & 鲤形目 & 鲤科 & 鲌亚科 & 飘鱼属 & & + & SLO & OMN & STD \\
\hline 44 & 鳊 Parabramis pekinensis & 鲤形目 & 鲤科 & 鲌亚科 & 鳊属 & V & + & SLO & HER & STI \\
\hline
\end{tabular}


续附表

\begin{tabular}{|c|c|c|c|c|c|c|c|c|c|}
\hline $\begin{array}{l}\text { 序 } \\
\text { 号 }\end{array}$ & 种类 & 目 & 科 & 亚科 & 属 & $\begin{array}{c}2013 \\
\text { 年 }\end{array}$ & $\begin{array}{l}\text { 文献 栖息 } \\
\text { 记录 生境 }\end{array}$ & 食性 & $\begin{array}{l}\text { 繁殖 } \\
\text { 习性 }\end{array}$ \\
\hline 45 & 海南似鱎 Toxabramis houdemeri & 鲤形目 & 鲤科 & 鲌亚科 & 似鱎属 & V & + SLO & $\mathrm{OMN}$ & STI \\
\hline 46 & ム小似鱎 T. hoffmanni & 鲤形目 & 鲤科 & 鲌亚科 & 似鱎属 & & + STI & OMN & STI \\
\hline 47 & 粲 Hemiculter leucisculus & 鲤形目 & 鲤科 & 鲌亚科 & 唋属 & V & + STI & OMN & PEL \\
\hline 48 & 伍氏半粲 Hemiculterella wui & 鲤形目 & 鲤科 & 鲌亚科 & 半駼属 & & + STI & $\mathrm{OMN}$ & PEL \\
\hline 49 & 细鳊 Rasborinus lineatus & 鲤形目 & 鲤科 & 鲌亚科 & 细鳊属 & & + SLO & OMN & STI \\
\hline 50 & 台细鳊 R. formosae (VU) & 鲤形目 & 鲤科 & 鲌亚科 & 细鳊属 & & + SLO & OMN & STI \\
\hline 51 & 大眼华鳊 Sinibrama macrops & 鲤形目 & 鲤科 & 鲌亚科 & 华鳊属 & V & SLO & OMN & STI \\
\hline 52 & 海南华鳊 S. melrosei & 鲤形目 & 鲤科 & 鲌亚科 & 华鳊属 & & + SLO & OMN & STI \\
\hline 53 & 南方拟餐 Pseudohemiculter dispar & 鲤形目 & 鲤科 & 鲌亚科 & 拟餐属 & V & + SLO & OMN & STI \\
\hline 54 & 海南拟粲 $P$. hainanensis & 鲤形目 & 鲤科 & 鲌亚科 & 拟餐属 & V & SLO & OMN & STI \\
\hline 55 & 三角鲂 Megalobrama thrminalis & 鲤形目 & 鲤科 & 鲌亚科 & 鲂属 & V & + STI & HER & STD \\
\hline 56 & 翅嘴鲌 Culter alburnus & 鲤形目 & 鲤科 & 鲌亚科 & 鲌属 & V & + STI & CAM & PEL \\
\hline 57 & 海南鲌 C. recurviceps & 鲤形目 & 鲤科 & 鲌亚科 & 鲌属 & V & + STI & CAM & PEL \\
\hline 58 & 蒙古鲌 C. mongolicus mongolicus & 鲤形目 & 鲤科 & 鲌亚科 & 鲌属 & & + STI & CAM & PEL \\
\hline 59 & 红鳍原鲌 Cultrichthys erythropterus & 鲤形目 & 鲤科 & 鲌亚科 & 原鲌属 & V & + STI & CAM & STI \\
\hline 60 & $\mathbf{\Delta}$ 大眼近红鲌 Ancherythroculter lini & 鲤形目 & 鲤科 & 鲌亚科 & 近红鲌属 & & + STI & CAM & PEL \\
\hline 61 & 银鲖 Xenocypris argentea & 鲤形目 & 鲤科 & 鲖亚科 & 鲖属 & V & + SLO & HER & PEL \\
\hline 62 & 黄尾鲖 X. davidi & 鲤形目 & 鲤科 & 鲖亚科 & 鲖属 & V & SLO & HER & PEL \\
\hline 63 & 鳙 Aristichthys nobilis & 鲤形目 & 鲤科 & 鲢亚科 & 鳙属 & V & + STI & OMN & PEL \\
\hline 64 & 鲢 Hypophthalmichthysmolitrix & 鲤形目 & 鲤科 & 鲢亚科 & 䱠属 & V & + STI & HER & PEL \\
\hline 65 & 唇鳃 Hemibarbus labeo & 鲤形目 & 鲤科 & 鮈亚科 & 䱻属 & V & + SLO & CAM & STI \\
\hline 66 & $\boldsymbol{\Delta}$ 间䱻 H. medius & 鲤形目 & 鲤科 & 鮈亚科 & 䱻属 & V & SLO & CAM & STI \\
\hline 67 & 花鳃 H. maculatus & 鲤形目 & 鲤科 & 鮈亚科 & 鳃属 & V & + SLO & CAM & STI \\
\hline 68 & 大刺鳃 H. macracanthus & 鲤形目 & 鲤科 & 鮈亚科 & 䱻属 & & + SLO & CAM & STI \\
\hline 69 & $\boldsymbol{\Delta}$ 花棘鳃 H. umbrifer & 鲤形目 & 鲤科 & 鮈亚科 & 鳃属 & V & SLO & CAM & STI \\
\hline 70 & 麦穗鱼 Pseudorasbora parva & 鲤形目 & 鲤科 & 鮈亚科 & 麦穗鱼属 & V & + STI & OMN & STD \\
\hline 71 & 小鳈 S. parvus & 鲤形目 & 鲤科 & 鮈亚科 & 鳈属 & & + SLO & OMN & PEL \\
\hline 72 & 银鮈 Squalidus argentatus & 鲤形目 & 鲤科 & 鮈亚科 & 银鮈属 & V & + SLO & OMN & PEL \\
\hline 73 & 片唇鮈 Platysmacheilus exiguous & 鲤形目 & 鲤科 & 鮈亚科 & 片唇鮈属 & V & SLO & OMN & STD \\
\hline 74 & 吻鮈 Rhinogobio typus & 鲤形目 & 鲤科 & 鮈亚科 & 吻鮈属 & V & SLO & CAM & PEL \\
\hline 75 & 棒花鱼 Abbotina rivularis & 鲤形目 & 鲤科 & 鮈亚科 & 棒花鱼属 & V & + STI & OMN & STD \\
\hline 76 & 福建小鳔鮈 Microphysogobio fukiensis & 鲤形目 & 鲤科 & 鮈亚科 & 小鳔鮈属 & V & SLO & OMN & STI \\
\hline 77 & 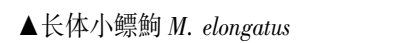 & 鲤形目 & 鲤科 & 鮈亚科 & 小鳔鮈属 & & + SLO & OMN & STI \\
\hline 78 & 乐山小鳔鮈 M. kiatingensis & 鲤形目 & 鲤科 & 鮈亚科 & 小鳔鮈属 & & + SLO & OMN & STI \\
\hline 79 & 似鲮小鳔鮈 M. labeoides & 鲤形目 & 鲤科 & 鮈亚科 & 小鳔鮈属 & & + SLO & OMN & STI \\
\hline 80 & 蛇鮈 Saurogobio dabryi & 鲤形目 & 鲤科 & 鮈亚科 & 蛇鮈属 & V & + SLO & OMN & PEL \\
\hline 81 & 海南鲉鮀 G. kolleri & 鲤形目 & 鲤科 & 鳅鮀亚科 & 鱾鮀属 & & + SLO & OMN & PEL \\
\hline 82 & 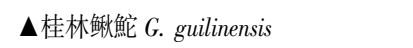 & 鲤形目 & 鲤科 & 鲉鮀亚科 & 鲉鮀属 & V & SLO & OMN & PEL \\
\hline 83 & 大鲲鱊 Acheilognathus macropterus & 鲤形目 & 鲤科 & 鱊亚科 & 鱊属 & & + STI & OMN & MUS \\
\hline 84 & 短须鱊A. babatulus & 鲤形目 & 鲤科 & 鱊亚科 & 鱊属 & & + STI & OMN & MUS \\
\hline 85 & 越南鱊 A. tonkinensis & 鲤形目 & 鲤科 & 鱊亚科 & 鱊属 & V & + STI & OMN & MUS \\
\hline 86 & 兴凯鱊A. chankaensis & 鲤形目 & 鲤科 & 鱊亚科 & 鱊属 & V & STI & OMN & MUS \\
\hline 87 & 高体鳑鲏 R. socellatus & 鲤形目 & 鲤科 & 鱊亚科 & 鳑鮍属 & V & + STI & OMN & MUS \\
\hline 88 & 刺鯺鳑鮍 R. spinalis & 鲤形目 & 鲤科 & 鱊亚科 & 鳑鮍属 & V & STI & OMN & MUS \\
\hline 89 & 广西副䁤Paracheilognathus meridianus & 鲤形目 & 鲤科 & 鱊亚科 & 副鱊属 & V & STI & OMN & MUS \\
\hline
\end{tabular}


续附表

\begin{tabular}{|c|c|c|c|c|c|c|c|c|c|}
\hline $\begin{array}{l}\text { 序 } \\
\text { 号 }\end{array}$ & 种类 & 目 & 科 & 亚科 & 属 & $\begin{array}{c}2013 \\
\text { 年 }\end{array}$ & $\begin{array}{l}\text { 文献 栖息 } \\
\text { 记录 生境 }\end{array}$ & 食性 & $\begin{array}{l}\text { 繁殖 } \\
\text { 习性 }\end{array}$ \\
\hline 90 & 条纹小鲃 Puntius semifasciolatus & 鲤形目 & 鲤科 & 鲃亚科 & 小鲃属 & & $+\mathrm{SLO}$ & HER & STD \\
\hline 91 & 光倒刺鲃 Spinibarbus hollandi & 鲤形目 & 鲤科 & 鲃亚科 & 倒刺鲃属 & V & + SLO & HER & STD \\
\hline 92 & 倒刺鲃 S. denticulatus & 鲤形目 & 鲤科 & 鲃亚科 & 倒刺鲃属 & V & + SLO & HER & STD \\
\hline 93 & 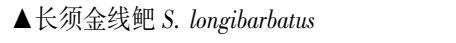 & 鲤形目 & 鲤科 & 鲃亚科 & 金线鲃属 & & + SLO & CAM & STD \\
\hline 94 & $\boldsymbol{\Delta}$ 东兰金线鲃 $S$. donglanensis & 鲤形目 & 鲤科 & 鲃亚科 & 金线鲃属 & & + SLO & CAM & STD \\
\hline 95 & $\boldsymbol{\Delta}$ 单纹似鳡 Luciocyprinus langsoni ( VU) & 鲤形目 & 鲤科 & 鲃亚科 & 似鳡属 & & + SLO & CAM & STD \\
\hline 96 & 带半刺光唇鱼 A. hemispinus cinctus & 鲤形目 & 鲤科 & 鲃亚科 & 光唇鱼属 & & + SLO & HER & STD \\
\hline 97 & 厚唇光唇鱼 A. labiatus & 鲤形目 & 鲤科 & 鲃亚科 & 光唇鱼属 & V & SLO & HER & STD \\
\hline 98 & 窄条光唇鱼 A. stenotaeniatus & 鲤形目 & 鲤科 & 鲃亚科 & 光唇鱼属 & V & SLO & HER & STD \\
\hline 99 & $\boldsymbol{\Delta}$ 北江光唇鱼 A. beïjangensis & 鲤形目 & 鲤科 & 鲃亚科 & 光唇鱼属 & V & SLO & HER & STD \\
\hline 100 & 细身光唇鱼 A. elongates & 鲤形目 & 鲤科 & 鲃亚科 & 光唇鱼属 & V & + SLO & HER & STD \\
\hline 101 & 侧条光唇鱼 A. parallens & 鲤形目 & 鲤科 & 鲃亚科 & 光唇鱼属 & V & SLO & HER & STD \\
\hline 102 & 云南光唇鱼 A.yunnanensis & 鲤形目 & 鲤科 & 鲃亚科 & 光唇鱼属 & & + SLO & HER & STD \\
\hline 103 & \多耙光唇鱼 A. clivosius & 鲤形目 & 鲤科 & 鲃亚科 & 光唇鱼属 & V & SLO & HER & STD \\
\hline 104 & $\Delta$ 长鯺光唇鱼 A. iridescens longipinnis & 鲤形目 & 鲤科 & 鲃亚科 & 光唇鱼属 & & + SLO & HER & STD \\
\hline 105 & 光唇鱼 A. fasciatus & 鲤形目 & 鲤科 & 鲃亚科 & 光唇鱼属 & V & SLO & HER & STD \\
\hline 106 & 粗须白甲鱼 Onychostoma barbata & 鲤形目 & 鲤科 & 鲃亚科 & 白甲鱼属 & & + SLO & HER & STD \\
\hline 107 & 南方白甲鱼 $O$. gerlachi & 鲤形目 & 鲤科 & 鲃亚科 & 白甲鱼属 & V & + SLO & HER & STD \\
\hline 108 & 小口白甲鱼 $0 . \operatorname{lini}(\mathrm{VU})$ & 鲤形目 & 鲤科 & 鲃亚科 & 白甲鱼属 & & + SLO & HER & STD \\
\hline 109 & 珠江卵形白甲鱼 0 . ovalis rhomboids & 鲤形目 & 鲤科 & 鲃亚科 & 白甲鱼属 & V & + SLO & HER & STD \\
\hline 110 & 稀有白甲鱼 $0 . r a r a(\mathrm{EN})$ & 鲤形目 & 鲤科 & 鲃亚科 & 白甲鱼属 & V & + SLO & HER & STD \\
\hline 111 & 瓣结鱼 Tor (Folifer) brevifilis brevifilis & 鲤形目 & 鲤科 & 鲃亚科 & 结鱼属 & & + SLO & HER & STD \\
\hline 112 & 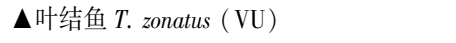 & 鲤形目 & 鲤科 & 鲃亚科 & 结鱼属 & & + SLO & HER & STD \\
\hline 113 & 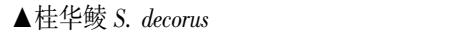 & 鲤形目 & 鲤科 & 野鲮亚科 & 华鲮属 & & + SLO & HER & STD \\
\hline 114 & 伍氏华鲮 Sinilabeo wui & 鲤形目 & 鲤科 & 野鲮亚科 & 华鲮属 & & + SLO & HER & STD \\
\hline 115 & 鲮 C. molitorella & 鲤形目 & 鲤科 & 野鲮亚科 & 鲮属 & V & + SLO & HER & STD \\
\hline 116 & 纹唇鱼 Osteocheilus salsburyi & 鲤形目 & 鲤科 & 野鲮亚科 & 纹唇鱼属 & V & + SLO & HER & STD \\
\hline 117 & $\Delta$ 直口鲮 Rectoris posehensis & 鲤形目 & 鲤科 & 野鲮亚科 & 直口鲮属 & V & + SLO & HER & STD \\
\hline 118 & $\boldsymbol{\Delta}$ 巴马拟缨鱼 Pseudocrossocheilus bamaensis & 鲤形目 & 鲤科 & 野鲮亚科 & 拟缨鱼属 & V & + RAP & HER & STD \\
\hline 119 & $\boldsymbol{\Delta}$ 柳城拟缆鱼 $P$. liuchengensis & 鲤形目 & 鲤科 & 野鲮亚科 & 拟缨鱼属 & & + RAP & HER & STD \\
\hline 120 & $\boldsymbol{\Delta}$ 异华鲮 Parasinilabeo assimilis & 鲤形目 & 鲤科 & 野鲮亚科 & 异华鲮属 & & + SLO & HER & STD \\
\hline 121 & 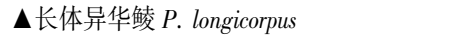 & 鲤形目 & 鲤科 & 野鲮亚科 & 异华鲮属 & & + SLO & HER & STD \\
\hline 122 & 暗色唇鲮 Semilabeo obscurus（VU) & 鲤形目 & 鲤科 & 野鲮亚科 & 唇鲮属 & V & $+\mathrm{RAP}$ & HER & STD \\
\hline 123 & 唇鲮 S. notabilis ( VU) & 鲤形目 & 鲤科 & 野鲮亚科 & 唇鲮属 & & $+\mathrm{RAP}$ & HER & STD \\
\hline 124 & 泉水鱼 Semilabeo prochilus & 鲤形目 & 鲤科 & 野鲮亚科 & 泉水鱼属 & & $+\mathrm{RAP}$ & HER & STD \\
\hline 125 & $\mathbf{\Delta}$ 卷口鱼 Ptychidio jordani & 鲤形目 & 鲤科 & 野鲮亚科 & 卷口鱼属 & V & + SLO & HER & STD \\
\hline 126 & 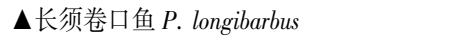 & 鲤形目 & 鲤科 & 野鲮亚科 & 卷口鱼属 & & + SLO & HER & STD \\
\hline 127 & 小口华缨鱼 Sinocrossocheilus microstomatus & 鲤形目 & 鲤科 & 野鲮亚科 & 华缨鱼属 & & + SLO & HER & STD \\
\hline 128 & 东方墨头鱼 Garra orientalis & 鲤形目 & 鲤科 & 野鲮亚科 & 墨头鱼属 & V & + RAP & HER & STD \\
\hline 129 & 云南盘鮈 Discogobio yunnanensis & 鲤形目 & 鲤科 & 野鲮亚科 & 盘鮈属 & & + RAP & HER & STD \\
\hline 130 & 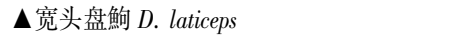 & 鲤形目 & 鲤科 & 野鲮亚科 & 盘鮈属 & & + RAP & HER & STD \\
\hline 131 & 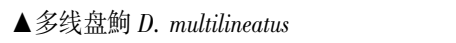 & 鲤形目 & 鲤科 & 野鲮亚科 & 盘鮈属 & V & + RAP & HER & STD \\
\hline 132 & $\boldsymbol{\Delta}$ 四须盘鮈 D. tetrabarbatus & 鲤形目 & 鲤科 & 野鲮亚科 & 盘鮈属 & V & + RAP & HER & STD \\
\hline 133 & 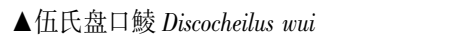 & 鲤形目 & 鲤科 & 野鲮亚科 & 盘口鯪属 & & + RAP & HER & STD \\
\hline 134 & 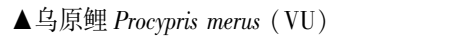 & 鲤形目 & 鲤科 & 鲤亚科 & 原鲤属 & & + SLO & $\mathrm{OMN}$ & STD \\
\hline
\end{tabular}


续附表

\begin{tabular}{|c|c|c|c|c|c|c|c|c|c|c|}
\hline $\begin{array}{l}\text { 序 } \\
\text { 号 }\end{array}$ & 种类 & 目 & 科 & 亚科 & 属 & $\begin{array}{c}2013 \\
\text { 年 }\end{array}$ & $\begin{array}{l}\text { 文献 } \\
\text { 记录 }\end{array}$ & $\begin{array}{l}\text { 栖息 } \\
\text { 生境 }\end{array}$ & 食性 & $\begin{array}{l}\text { 繁殖 } \\
\text { 习性 }\end{array}$ \\
\hline & $\boldsymbol{\Delta}$ 三角鲤 Cyprinus multitaeniata & 鲤形目 & 鲤科 & 鲤亚科 & 鲤属 & V & + & SLO & OMN & STD \\
\hline 136 & 鲤 Cyprinus (Cyprinus) carpio & 鲤形目 & 鲤科 & 鲤亚科 & 鲤属 & V & + & STI & OMN & STI \\
\hline 137 & 须鲫 Carassioides cantonensis & 鲤形目 & 鲤科 & 鲤亚科 & 须鲫属 & & + & STI & $\mathrm{OMN}$ & STI \\
\hline 138 & 鲫 Carassius auratus & 鲤形目 & 鲤科 & 鲤亚科 & 鲫属 & V & + & STI & OMN & STI \\
\hline 139 & 平舟原缨口鱾 Vanmanenia pingchowensis & 鲤形目 & 平鯺鲉科 & 腹吸䱊亚科 & 原缨口鳅属 & & + & RAP & HER & STD \\
\hline 140 & 信宜原鹦口䲝 V. xinyiensis & 鲤形目 & 平鯺鲀科 & 腹吸鱾亚科 & 原缨口鲉属 & & + & RAP & HER & STD \\
\hline 141 & 平头原缨口䱌 V. hamalocephala & 鲤形目 & 平鯺鲀科 & 腹吸鳅亚科 & 原缨口鲉属 & & + & RAP & HER & STD \\
\hline 142 & $\Delta$ 巴马似原吸鲉 Paraprotomyzon bamaensis & 鲤形目 & 平鯺鲉科 & 腹吸䱊亚科 & 似原吸鲉属 & & + & RAP & HER & PEL \\
\hline 143 & $\Delta$ 中华原吸䲝 Protomyzon sinensis & 鲤形目 & 平鯺鳅科 & 腹吸鱾亚科 & 原吸鲀属 & V & & RAP & HER & PEL \\
\hline 144 & $\Delta$ 秉氏爬岩鱾 Beaufortia pingi & 鲤形目 & 平鯺鲉科 & 腹吸鱾亚科 & 爬岩鱾属 & & + & RAP & HER & STD \\
\hline 145 & 广西华平鱾 Sinohomaloptera kwangsiensis & 鲤形目 & 平鯺鲉科 & 平鯺鳅亚科 & 华平鱾属 & V & + & RAP & HER & STD \\
\hline 146 & 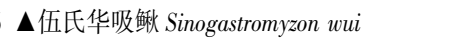 & 鲤形目 & 平鯺鲉科 & 平鯺鳅亚科 & 华吸鲀属 & V & + & RAP & HER & STD \\
\hline 147 & 鲇 Silurus asotus & 鲇形目 & 鲇科 & & 鲇属 & V & + & STI & CAM & STI \\
\hline 148 & $\boldsymbol{\Delta}$ 西江鲇 $S$. gilberti & 鲇形目 & 鲇科 & & 鲇属 & V & + & SLO & CAM & STI \\
\hline 149 & 越南鲇 S. cochinchinensis & 鲇形目 & 鲇科 & & 鲇属 & V & + & SLO & CAM & STI \\
\hline 150 & \都安鲇 S. duanensis & 鲇形目 & 鲇科 & & 鲇属 & V & + & SLO & CAM & STI \\
\hline 151 & 大口鲇 S. meridionalis & 鲇形目 & 鲇科 & & 鲇属 & V & & STI & CAM & STI \\
\hline 152 & 胡子鲇 Clarias batrachus & 鲇形目 & 胡子鲇科 & & 胡子鲇属 & V & + & STI & CAM & STI \\
\hline 153 & $\triangle$ 革胡子鲇 C. gariepinus & 鲇形目 & 胡子鲇科 & & 胡子鲇属 & V & & STI & CAM & STI \\
\hline 154 & 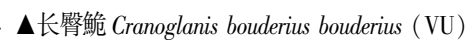 & 鲇形目 & 长臀鮠科 & & 长臀鯔属 & V & + & SLO & CAM & STD \\
\hline 155 & 黄颡鱼 Pelteobagrus fulvidraco & 鲇形目 & 魭科 & & 黄颡鱼属 & V & + & STI & OMN & NES \\
\hline 156 & 中间黄滪鱼 P. intermedius & 鲇形目 & 魭科 & & 黄颞鱼属 & V & + & STI & OMN & NES \\
\hline 157 & 瓦氏黄颡鱼 Pelteobagrus vachelli & 鲇形目 & 鲿科 & & 黄颡鱼属 & V & + & STI & OMN & NES \\
\hline 158 & 粗唇鮠 Leiocassis crassilabris & 鲇形目 & 魭科 & & 鮸属 & V & + & SLO & CAM & STD \\
\hline 159 & 条纹鮠 L. virgatus & 鲇形目 & 魭科 & & 鮠属 & & + & SLO & CAM & STD \\
\hline 160 & $\mathbf{\Delta}$ 纵带鮸 L. argentivittatus & 鲇形目 & 魭科 & & 鯔属 & & + & SLO & CAM & STD \\
\hline 161 & 乌苏拟鲿 Pseudobagrus ussuriensis & 鲇形目 & 魭科 & & 拟鲿属 & V & & SLO & CAM & STD \\
\hline 162 & 斑鳠 Mystus guttatus & 鲇形目 & 魭科 & & 鳠属 & V & + & SLO & CAM & STD \\
\hline 163 & 大魦鳠 M. macropterus & 鲇形目 & 魭科 & & 鳠属 & V & + & SLO & CAM & STD \\
\hline 164 & 福建纹胸鮡 Glyptothorax fukianensis & 鲇形目 & 鮡科 & & 纹胸鮡属 & V & + & RAP & CAM & STD \\
\hline 165 & $\Delta$ 长尾鮡 Pareuchiloglanis longicauda & 鲇形目 & 鮡科 & & 鮡属 & & + & RAP & CAM & STD \\
\hline 166 & $\boldsymbol{\Delta}$ 巨修仁鲆 $X$. gigas & 鲇形目 & 针头鮸科 & & 修仁 属 & & + & SLO & CAM & STD \\
\hline 167 & $\triangle$ 斑点叉尾鮰 Ictalurus punctatus & 鲇形目 & 鮰科 & & 鮰属 & V & & STI & CAM & STD \\
\hline 168 & 间下鱵 Hyporamphus intermedius & 领针鱼目 & 鱵科 & & 下鱵属 & & + & EST、SLO & CAM & STI \\
\hline 169 & 青鲟 Oryzias latipes（VU) & 鳉形目 & 青鲟科 & & 青鲟属 & & + & STI & CAM & STI \\
\hline 170 & $\triangle$ 食蚊鱼 Gambusia affinis & 鳉形目 & 胎鳞科 & & 食蚊鱼属 & V & & STI & OMN & OVO \\
\hline 171 & 黄鳝 Monopterus albus & 合鳃鱼目 & 合鳃鱼科 & & 黄鳝属 & V & + & STI & OMN & PEL \\
\hline 172 & 花鲈 Lateolabrax japonicus & 鲇形目 & 鮨科 & 常鲈亚科 & 花鲇属 & & + & EST、SLO & CAM & STD \\
\hline 173 & 中国少鳞䲆 Coreoperca whiteheadi & 鲇形目 & 鮨科 & 䰻亚科 & 少鳞䱻属 & V & + & RAP & CAM & STD \\
\hline 174 & 波纹鲖 S. undulate (VU) & 鲇形目 & 鮨科 & 䰻亚科 & 鳜属 & V & + & RAP & CAM & STD \\
\hline 175 & 斑鳜 S. scherzeri & 鲇形目 & 鮨科 & 鲭亚科 & 鳜属 & V & + & SLO & CAM & STD \\
\hline 176 & 大眼鰦 S. kneri & 鲇形目 & 鮨科 & 鳜亚科 & 鰄属 & V & + & SLO & CAM & STD \\
\hline 177 & $\triangle$ 鳎 Siniperca chuatsi & 鲈形目 & 鮨科 & 鳇亚科 & 鲬属 & V & & SLO & CAM & STD \\
\hline 178 & $\triangle$ 莫桑比克罗非鱼 Tilapia mossambica & 鲇形目 & 丽鱼科 & & 罗非鱼属 & V & & STI & OMN & STI \\
\hline 179 & $\triangle$ 尼罗罗非鱼 T. niloticus & 鲇形目 & 丽鱼科 & & 罗非鱼属 & V & & STI & OMN & STI \\
\hline
\end{tabular}


续附表

\begin{tabular}{|c|c|c|c|c|c|c|c|c|c|}
\hline $\begin{array}{l}\text { 序 } \\
\text { 号 }\end{array}$ & 目 & 科 & 亚科 & 属 & $\begin{array}{c}2013 \\
\text { 年 }\end{array}$ & $\begin{array}{l}\text { 文献 } \\
\text { 记录 }\end{array}$ & $\begin{array}{l}\text { 栖息 } \\
\text { 生境 }\end{array}$ & 食性 & $\begin{array}{l}\text { 繁殖 } \\
\text { 习性 }\end{array}$ \\
\hline $180 \triangle$ 奥里亚罗非鱼 T. aureus & 鲈形目 & 丽鱼科 & & 罗非鱼属 & V & & STI & OMN & STI \\
\hline 181 中华沙塘鳢 Odontobutis sinensis & 鲇形目 & 沙塘鳢科 & & 沙塘鳢属 & & + & SLO & CAM & PEL \\
\hline 182 尖头塘鳢Eleotris oxycephala & 鲇形目 & 塘鳢科 & & 塘鳢属 & V & + & SLO & CAM & PEL \\
\hline 183 乌塘鳢 Bostrychus sinensis & 鲇形目 & 塘鳢科 & & 乌塘鳢属 & V & & SLO & CAM & PEL \\
\hline 184 沙塘鳢 Odontobutis obscurus & 鲇形目 & 塘鳢科 & & 沙塘鳢属 & V & & SLO & CAM & PEL \\
\hline 185 海南细齿塘鳢 Philypnus chalmersi & 鲇形目 & 塘鳢科 & & 细齿塘鳢属 & & + & SLO & CAM & PEL \\
\hline 186 大鳞细齿塘鳢 $P$. hainanensis & 鲇形目 & 塘鳢科 & & 细齿塘鳢属 & & + & SLO & CAM & PEL \\
\hline 187 粘皮鲻鰕虎鱼 Mugilogobius myxodermus & 鲇形目 & 鰕虎鱼科 & & 鲳鰕虎鱼属 & & + & SLO & CAM & STD \\
\hline 188 舌鰕虎鱼 Glossogobius giuris & 鲇形目 & 鰕虎鱼科 & & 舌鰕虎鱼属 & V & + & EST、STI & CAM & STD \\
\hline 189 子陵吻鰕虎鱼 Rhinogobius giurinus & 鲇形目 & 鰕虎鱼科 & & 吻鰕虎鱼属 & V & + & STI & CAM & STD \\
\hline 190 溪吻鰕虎鱼 $R$. duospilus & 鲇形目 & 鰕虎鱼科 & & 吻鰕虎鱼属 & & + & STI & CAM & STD \\
\hline 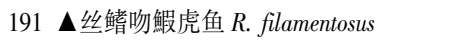 & 鲇形目 & 鰕虎鱼科 & & 吻鰕虎鱼属 & & + & STI & CAM & STD \\
\hline 192 李氏吻鰕虎鱼 $R$. leavelli & 鲇形目 & 鰕虎鱼科 & & 吻鰕虎鱼属 & & + & STI & CAM & STD \\
\hline 193 叉尾斗鱼 Macropodus opercularis & 鲇形目 & 斗鱼科 & & 斗鱼属 & & + & STI & CAM & PEL \\
\hline 194 圆尾斗鱼 M. chinensis & 鲇形目 & 斗鱼科 & & 斗鱼属 & & + & STI & CAM & PEL \\
\hline 195 斑鳢Channa maculate & 鲇形目 & 鳢科 & & 鳢属 & V & + & STI & CAM & NES \\
\hline 196 月鳢 C. asiatica & 鲇形目 & 鳢科 & & 鳢属 & V & + & STI & CAM & NES \\
\hline 197 大刺鱾 M. armatus & 鲇形目 & 刺鲉科 & & 刺鱾属 & V & + & SLO & OMN & STD \\
\hline 198 三线舌鳎 Cynoglossus trigrammus & 鰈形目 & 舌鰨科 & & 舌鲳属 & & + & EST、SLO & CAM & STD \\
\hline 199 弓斑东方鲀 Takifugu ocellatus & 鲀形目 & 鲀科 & & 东方鲀属 & V & + & EST、SLO & CAM & STD \\
\hline 合计 & & & & & 122 & 161 & & & \\
\hline
\end{tabular}

* 国家级保护鱼类, $\boldsymbol{\Delta}$ 特有鱼类, $\triangle$ 外来鱼类; EN 濒危, VU 易危; $V$ 表示 2013 年调查采集到, +表示历史记录有分布; MIG 洄游鱼类、EST 河口鱼类、RAP 急流、SLO 缓流、STI 静水; CAM 肉食性, HER 植食性, OMN 杂食性; PEL 漂流性卵,STD 粘 沉性卵, STI 粘性卵, PEL 浮性卵, OVO 卵胎生, MUS 蛙内产卵鱼类, NES 筑巢产卵鱼类. 